\title{
Soup and Reform: Improving the Poor and Reforming Immigrants through Soup Kitchens 1870-1910
}

\author{
Philip Carstairs ${ }^{1}$
}

Published online: 11 March 2017

(C) The Author(s) 2017. This article is published with open access at Springerlink.com

\begin{abstract}
Charitable soup kitchens proliferated in nineteenth-century Europe and North America. Three soup kitchens operating in England between 1870 and 1910 are compared; two were Jewish soup kitchens, the other was an English (non-Jewish) charity. Institutional buildings are often analyzed using Foucault-derived models of control based on surveillance and punishment. Such models may not explain fully charities, their buildings, or their method of reform. Historical archaeology can show how charity that coerces or dehumanizes the poor is less likely to create lasting improvements in the behaviors it is seeking to reform than charity that adopts a more positive approach.
\end{abstract}

Keywords Philanthropy· Charity·Building · Soup kitchen · England

\section{Background}

\section{Introduction}

Charitable distribution of food to the poor has been part of almost every religious and cultural tradition, but this has not prevented people from debating who should benefit from charity and what form charity should take. In the increasingly secular modern world, welfare is called on to perform the role of state philanthropy and has so become one of the most contested and debated topics while at the same time showing significant cross-cultural variation. Welfare reform and how to deal with "the poor" have been high on the political agenda in recent times, and food banks and soup kitchens have opened up in many western countries since the onset of economic crisis of 2008.

Philip Carstairs

pjc51@le.ac.uk

1 School of Archaeology and Ancient History, University of Leicester, University Road, Leicester LE1 7RH, UK 
Despite the importance of charity and welfare, few historical or archaeological studies that have considered the subjects in any depth. By exploring how charity operated, how it was experienced and its consequences (did the recipients benefit?) historical archaeology can inform the debate and highlight the shortcomings of past and present approaches to welfare. The giving of alms to the poor in the form of food is advocated in Judaism (Isaiah 58:7, Proverbs 22: 9; Maimonides 1979), Islam (Surah 89, 90 and 107) and Christianity (Matthew 25: 5-40, Luke 3:11). Soup kitchens are part of this long history of the charitable distribution of food. In Western Europe, soup kitchens appear in the late seventeenth century. They spread rapidly throughout northern Europe and North America in the late eighteenth and early nineteenth centuries. This article places three soup kitchens that operated in England between 1870 and 1910: the General Soup Kitchen, an English ("English" is used for convenience to mean non-Jewish; many of the Anglo-Jewish community were English born) soup kitchen in Newcastle, the Soup Kitchen for the Jewish Poor in London, and the Manchester Jewish Soup Kitchen at the Philanthropic Hall in Manchester (Fig. 1), in the broader context of the development of charities, the English Poor Laws and the growth of the Anglo-Jewish community, in each case from the eighteenth century through to the First World War. Using the buildings, the material culture and documentary evidence from the Newcastle, London, and Manchester soup kitchens in turn, the article explores the different ways in which the Jewish and English charities influenced, reformed and controlled the poor. Soup kitchens differ both from modern food charities such as food banks and breadlines, and their ancestor, the bread, meat, and coal society, by cooking and serving ready-to-eat meals. This required specialized premises and a degree of permanence making them more amenable to archaeological study.

\section{Archaeology of Buildings}

Institutional buildings can express the ideologies upon which they operate both externally and internally (Piddock 2007). For example, many of the large institutional buildings of the eighteenth and nineteenth centuries often adopted the style of palaces or country houses (Markus 1993). Their appearance embodied the good taste and power of the benefactors and communicated their reformative goals to those outside. State institutions that dealt with pathology, such as prisons (Brodie et al. 2002; Casella 2001, 2007) and workhouses (May 2005; Markus 1993) adopted designs that facilitated categorizing, segregating, controlling, and exercising surveillance over those inside. The concepts of the total institution (Goffman 1961) and of dominance and control (Foucault 1979) have been very influential in the study of institutional buildings. Some charitable institutions have been found to conform to the pattern, for example, the Philadelphia Magdalen Society (De Cunzo 1995) and almshouses (Baugher 2001; Huey 2001; Spencer-Wood 2001).

Soup kitchens transformed raw ingredients into soup (in very large quantities) and hungry people into fed and hopefully content people. The processes, the flows of material and people, and the performance of daily life within the space both influence and are influenced by the physical structure (Johnson 2010). Understanding how transformations took place helps explain the charitable relationship between rich and poor. Sherman (2001) argues that between 1790 and 1805, the pamphlets, books and 


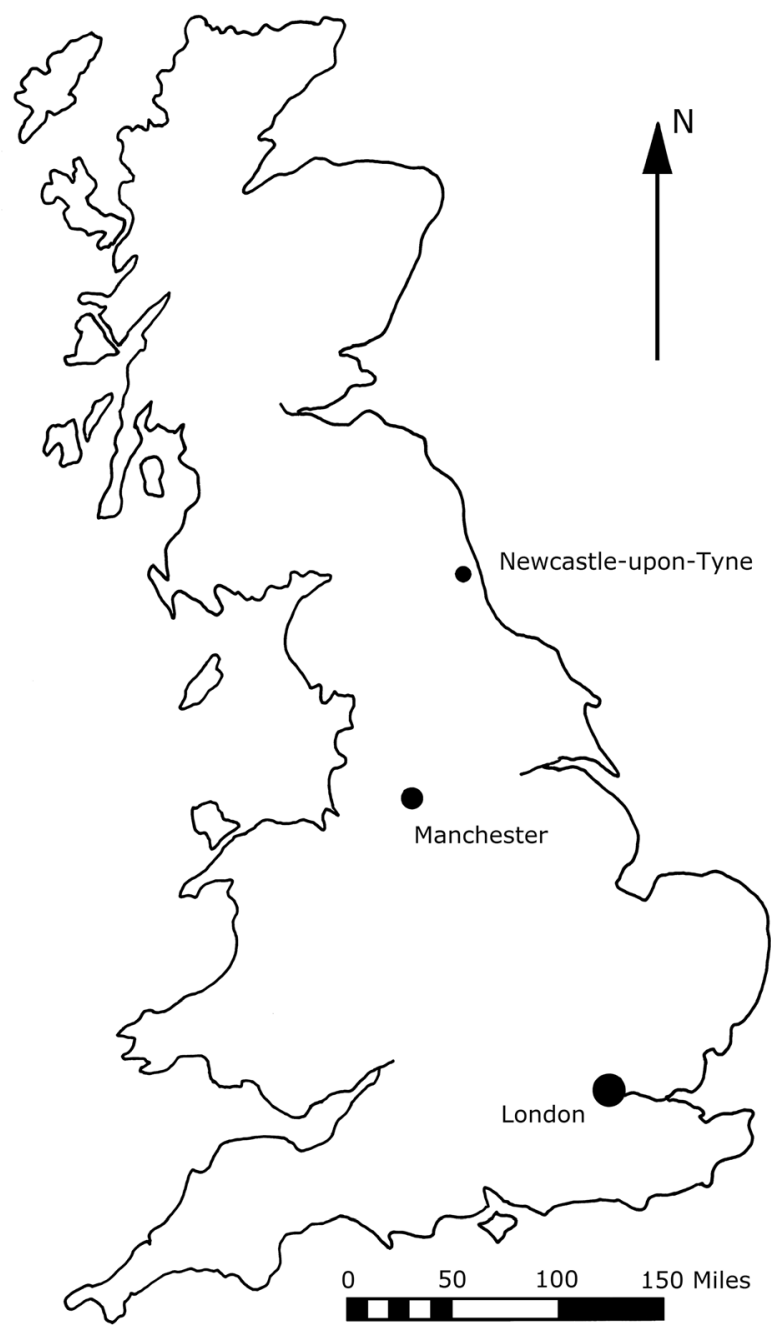

Fig. 1 The location of the London, Newcastle, and Manchester soup kitchens (drawing: author)

articles that promoted soup and soup kitchens transformed the ways in which the upper classes viewed the poor and how the poor viewed themselves. Below, I consider whether buildings operated in a similar way.

\section{Charity and Philanthropy 1750-1914}

The soup kitchens studied here considered themselves to be charities and acting philanthropically. Welfare delivered by charity is, and was, distinguished from "state" welfare, financed by taxes. The two were nevertheless closely intertwined through much of the nineteenth century. The fact that some soup kitchens charged nominal amounts for soup does not make them uncharitable (contra Cordeiro 2012). Benefaction for the purpose of mitigating poverty, disease, infirmity, or ignorance (Owen 1965), acts intended for another's moral, social, or physical good (Checkland 
1980), as well as acts of personal kindness, neighborliness, and mutual aid (Prochaska 1990) encompass much of what was considered charity or philanthropy. Here, charity and philanthropy are treated as being synonymous, reflecting the historical usage although some writers have distinguished between the two (e.g., Checkland 1980; Rozin 1999).

By the mid-eighteenth century charitable associations, modelled on commercial joint-stock companies, in which each contributor was a member who had a vote and the ability to direct the way in which the charity operated, were becoming increasingly popular among benefactors. The middle class could participate in much grander schemes than mere almsgiving which was beginning to be perceived as a problem for encouraging begging while not reaching the truly deserving (Owen 1965; Prochaska 1990). The development of the charitable association within the English Christian community marks a shift from the view that charity was an obligation for all Christians to the view that it was a useful voluntary activity that was practical and social but still derived from religious duties such as mercy and compassion (Andrew 1989). The shift is often described as being from a personal, paternalistic exchange of obligation and reciprocal gratitude to a formal organized process of benefaction and improvement. The systematic organization of charitable effort enabled and indeed required charitable associations to promote their agenda. Subscribers were often discriminating in selecting the objects of their benefaction, favoring institutions which were efficient and reflected their moral beliefs.

Expert opinions on welfare, charity and reform were widely published. Laissez-faire economics, which placed an emphasis on the free market and individuals' responsibility for their own well-being, underlay much of the late eighteenth- and nineteenthcentury expert thinking about welfare reform, but the reasons why ordinary people became involved in charity are harder to fathom. Organizers and subscribers were usually motivated by a combination of piety, humanitarianism, utilitarianism, and probably self-interest (preventing unrest, ensuring a good supply of cheap labor, reinforcing the social hierarchy, or enhancing one's social standing) (Stedman Jones 2013; Sherman 2001). However, these explanations underestimate the complexity of people's motives (Prochaska 1990).

\section{The Poor Laws and State Welfare in England 1790-1914}

Public welfare in the eighteenth and nineteenth centuries in England was very limited; its mainstay was outdoor relief, the provision of cash, food, clothing and winter fuel, under the Poor Laws; indoor relief, meaning confinement in the workhouse, was only used for a small proportion of the poor (Fraser 2009). The Poor Laws divided the poor into the impotent (the aged, blind, sick, or mad), who would be accommodated in poorhouses or almshouses; the able-bodied, who were to be set to work in a nonresidential workhouse; and the persistent idlers, who were to be sent to a house of correction if they refused to work. Each parish was only responsible for those who had the right of settlement there (either by birth or long-term residence) and paid for the relief by collecting a local poor tax. Each locality adopted its own interpretation of the Poor Laws and practiced what it felt it could afford; it was cheaper to provide outdoor relief. Parishes, particularly urban ones, with higher concentrations of poor people inevitably suffered higher taxes and lower levels of relief. 
The English rate-payers, by and large, accepted the burden of poor relief up to 1815 , at the end of the Napoleonic wars (Fraser 2009). Nevertheless, there were significant free-market advocates who felt that any form of relief demoralized the poor, made them dependent, and removed their will to adopt self-help remedies (Digby 1989). After 1815 , the economy remained sluggish and there were signs of growing civil unrest. The demand increased for reform of the old Poor Laws, which some perceived to be the cause of the problem.

The 1834 Poor Law Amendment Act was centered on promoting self-help by severely restricting outdoor relief, leaving the workhouse as the only form of welfare for most. The workhouse regime became so unpleasant that any form of work was preferable and only the truly desperate would ever agree to be admitted (Humphreys 1995). The new law assumed that individuals were masters of their own destiny and therefore that poverty was a personal failing and the result of choice (Fraser 2009). To qualify for any relief, applicants had to agree to pass the "workhouse test" by entering the workhouse and performing a specified task, such as breaking stones or picking oakum. However, the new legislation was interpreted differently across the country; in many areas the workhouse test was not rigorously applied and outdoor relief continued to be available to individuals who were willing to undertake a small laboring task. Five out of six paupers were still given outdoor relief rather than being sent to the workhouse (Fraser 2009). The failure of the new law to promote self-help and create a nation of striving and successful individuals was not anticipated by its proponents. This inability of state institutions from the eighteenth century onwards to deal with the periodic but unpredictable hard times resulting was doubtless a major spur to the development of privatelyfunded and organized philanthropy that targeted issues of public concern. Soup kitchens formed part of that charitable response.

By the late 1860s, poverty and social problems were still growing despite the legal reforms, the growing number of charities, and the increasing amounts of money being spent. The idea of a more scientific charity had been developing during the nineteenth century and in 1869 the Charitable Organisation Society (the COS) was formed (Humphreys 1995). The COS was not a state body, but it set itself the task of curtailing indiscriminate almsgiving and controlling charities that were active in the relief of poverty. The COS thought that misapplied charity demoralized the poor and created a dangerous class of welfare-dependent paupers adept at manipulating "the system," thereby undermining the effectiveness of the Poor Law. If charities properly investigated the circumstances of the poor and only then applied the correct sort of relief, the poor would become capable of looking after themselves. The COS began a reactionary crusade against outdoor relief that set the agenda for the later part of the nineteenth century (Hurren 2007). The crusaders wanted to revert to a strict implementation of the 1834 Poor Law, doing away with all forms of outdoor relief. The crusade never did prevail everywhere, but its influence, even in areas that persisted with a more moderate welfare policy, was considerable. By the 1880s "new liberal" experts, such as Samuel Barnett, Arnold Toynbee, and Alfred Marshall, were beginning to consider whether poverty had wider, more structural causes, deeper than simple personal or moral failing and by the twentieth century the crusade had petered out and reformers such as William Booth and Joseph Rowntree prompted a shift in attitudes in favor of greater state 
intervention (Stedman Jones 2013). However, public opinion has always been slower to shift, even in the face of expert opinion; even today, the welfare debate reiterates many of the nineteenth-century views.

\section{The Anglo-Jewish Community 1660 to 1914}

London's Jewish community numbered about 20,000 in 1850 , about two-thirds of whom lived in a small area immediately east of the City of London, the commercial heart of the metropolis (Lipman 1954). The Jewish community had first settled there following their informal readmission to England in 1656, 366 years after they had been expelled by King Edward I. The early Sephardic settlers were from the Netherlands, Portugal, and Spain, and were mainly merchants. They opened their first synagogue in 1657 on Creechurch Lane, Aldgate; this was replaced by a larger synagogue in nearby Bevis Marks in 1701. The Ashkenazi community was largely German in origin and although some of its members achieved great wealth as merchants and bankers, most were poor. The first Ashkenazi synagogue was established in 1690 in Duke's Place, Aldgate. This was replaced by a much larger synagogue, known as the Great Synagogue, on the same site in 1790, by which time two further Ashkenazi synagogues, Hambro' (established in1707) and the New Synagogue (established in1761) had broken away from the Great Synagogue. England was attractive to Jewish immigrants because of the economic opportunities and the relative freedom in comparison to other European cities (Lipman 1990). As welfare was initially synagogue-based, the Sephardic and Ashkenazi communities did not participate in each other's charities, leaving the poorer Ashkenazi at a disadvantage (Rozin 1999). Both soup kitchens discussed here were Ashkenazi.

The Jewish male community gained full emancipation in 1858/60, about 20 years after male Catholics and dissenters (i.e., protestant Christians who were not members of the Church of England). During the eighteenth century the Jewish community gradually established itself and grew largely through increasing numbers of Ashkenazim (Lipman 1994). The synagogues were the main source of relief in the London Jewish community, other than personal almsgiving. The synagogue authorities divided the poor into three categories for the purposes of allocating relief: the stipendiary poor, members of the synagogue who received a relatively generous monthly dole; the casual poor, who might be associated with the synagogue via a family member or from renting a seat there; and the "stranger poor," Jews who had no claim on any synagogue (Lipman 1959). The casual and stranger poor were less well-cared-for; the dues payable for synagogue membership would have been beyond their means. The stranger poor had to apply to each of the three Ashkenazi synagogues for their dole. The Great Synagogue contributed half of the expenses while each of the other two synagogues contributed a quarter of the relief distributed. Cooperation between the synagogues sometimes broke down as each tried to avoid responsibility for expenses that it considered lay elsewhere; Lipman (1954) cites an example of a coffin being left in the middle of Duke's Place in 1790 because the synagogues could not agree which of them was responsible for its burial.

The "van Oven scheme," an attempt circa 1800 to establish a statutory Jewish welfare system, failed (Endelman 2002). In 1804, the three Ashkenazi synagogues 
agreed that the Great Synagogue would administer the relief of the stranger poor with the costs shared on the same basis as before. Relief for the Jewish poor was probably more generous than the English or Irish received (Lipman 1959), but there were allegations by both established Jews and some of the English community that the relief was pauperizing and encouraging immigrants (Rozin 1999). With the curtailment of outdoor relief under the new Poor Laws in 1834, the Jewish community became concerned about fellow Jews being sent to the workhouse, where none of the Jewish dietary laws or other customs could be observed. There was a significant increase in charitable activity (Lipman 1954) but it tended to favor the stipendiary poor and reflected the prevailing organizational structure, style, and strict moral outlook of English charities.

The push of increasing persecution in Eastern Europe and the pull of economic opportunity brought increasing numbers of Jewish immigrants to England during the mid-nineteenth century. Lipman $(1954,1990)$ estimates that the number of new settlers (excluding the many transmigrants and those repatriated) increased from about 300 a year between 1800 and 1850, to 500 in 1858, and 1000 in 1881; between 1890 and 1902 somewhere between 5000 and 8000 arrived annually in London. Half as many again arrived in east-coast ports such as Hull and Grimsby. Many of the new arrivals went to Manchester. Most were desperately poor.

Manchester's Jewish community was much smaller than London's in the first half of the nineteenth century, although it grew very rapidly. Manchester itself had a population of 80,000 in 1800 ; by mid-century its population was 250,000 and by 1914 it was 2,000,000 (Liedtke 1998). The Jewish community in Manchester numbered about 60 people in 1790, growing to 600 by 1825 and 2000 by 1858 (Marks 2014). By 1900, the Jewish population of Manchester was 25,000, making it the second largest such community in Britain after London, where about 150,000 Jews lived (Lipman 1954).

The population growth in both cities exposed the gaps in the underfunded patchwork of charitable and synagogue-based relief at a time when the increasingly anglicized middle-class Jews were migrating towards the suburbs (Lipman 1954; Williams 1976). This shift was no different to that taking place in the English community (Stedman Jones 2013) and resulted in increasing physical and psychological distance between the very poor and the better-off. The Anglo-Jewry were now faced with several issues, including growing numbers of poor who were "their own people" but were also foreign and potentially troublesome; they were concerned that they would be blamed for the social problems caused by the new arrivals; and furthermore, some of the new immigrants brought with them socialist and anarchist ideologies (Lipman 1994).

Jews in both cities set about reorganizing their charitable efforts by setting up Boards of Guardians modelled on contemporary English poor law boards. The Board of Guardians in London was established in 1859 (Lipman 1959) and in Manchester in 1867 (Liedtke 1998). Neither body had legal authority, unlike their English counterparts, but there was an expectation in both the Jewish and the English communities that the Jews would "look after their own." The London Board was initially set up to deal only with the stranger poor, but this limitation was abandoned in the 1860 s because the majority of the poor were not recent arrivals; over a quarter of all London Jews received relief from the London Board between 1869 and 1882 (Lipman 1990). Both Boards acted as fundraising bodies and clearing houses for applicants for relief, either providing relief directly or through existing charities. Their key principles were organization, 
investigation of requests for relief, and prompt and appropriate relief; these were the first steps towards professionalizing welfare. The creation of the Boards presages the arrival of the COS; the anglicized Jews voiced similar concerns about indiscriminate charity, pauperization, duplication of effort, and exploitation by the "clever pauper" (Rozin 1999).

The growing numbers of mostly poor rural-born eastern Europeans (of all faiths) resulted in greater underemployment and overcrowding in areas of both cities that were already densely populated. Figure 2 shows the east London streets in 1899 that were more than $50 \%$ Jewish in shaded grey with the black being more than 95\% Jewish, whereas the white is less than 5\% Jewish (Russell and Lewis 1900). In Manchester, the Jewish settlement was concentrated to the north of the city center in Red Bank (Vaughan 2002), but spread across Cheetham Hill to the west as far as Strangeways Prison. In 1871, a third of Jews there had been born in Russia or Poland, resulting in Yiddish being the dominant language in the early 1900s (Liedtke 1998). As the density of Jewish settlement in the later-nineteenth century increased, new arrivals were prepared to put up with over-crowded accommodation and lower wages, and racial tensions and anti-Semitism grew, including the open publication of anti-Semitic views in the press (Lipman 1981).

At first, the Boards of Guardians seriously underestimated the scale of the problem and simply encouraged the new arrivals to move on elsewhere or to go back to Eastern

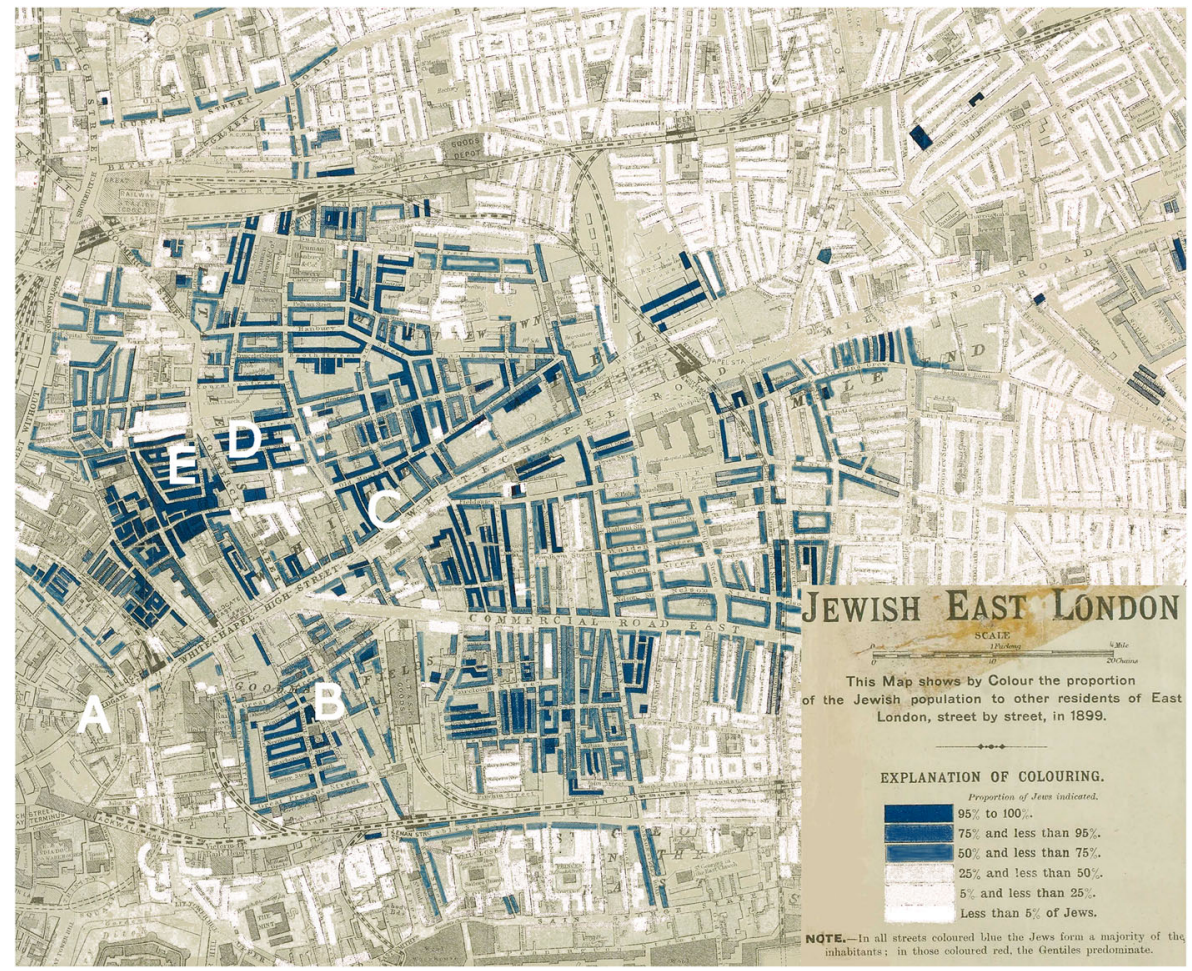

Fig. 2 Jewish East London in 1899 (Russell and Lewis 1900) with the locations of the Jewish soup kitchen added, Mitre Court (a), 31 Leman Street (b), Black Lion Yard (c), Fashion Street (d) and Butler Street (e) added (map courtesy of the Museum of London) 
Europe. When this strategy failed, London Board adopted a policy of denying any relief (other than a ticket back home) to applicants who had not been resident for at least six months to avoid the accusation that their relief policies were attracting new immigrants. The Board advertised this policy in Eastern Europe. The Manchester Board adopted a slightly less stringent regime, giving those who had been in the city for less than six months reduced levels of relief (Liedtke 1998). This failed to stem the tide and created resentment as the policy was contrary to traditional Jewish values (Rozin 1999). Whether the policies were actually put into practice, or were more rhetorical, to appease the English and the Anglo-Jewish establishment and show that their welfare policies did not encourage immigration is not clear. The London Board only rejected about 5\% of applicants for relief (Lipman 1990). The English categories of deserving and undeserving poor could not be applied to the combination of desperately poor economic migrants and refugees arriving from Eastern Europe - over 20\% arrived with no money (Lipman 1990).

The Boards of Guardians devoted significant efforts to ensure that relief was linked to improvement. Families had to enroll their children in school and learn English to remain entitled to relief; cash doles were restricted and aid was given in the form of apprenticeship schemes, loans of cash or equipment to set up businesses. The ablebodied could only receive relief for six months without being subject to further investigation. The Boards attempted to push Jews into trades that were less subject to seasonal fluctuations and encouraged improvements in sanitation and housing in the Jewish East End (Lipman 1959). They were also criticized for being overbearing and either stamping out or taking control of charitable schemes they disapproved of, such as the attempts to develop a Jewish workhouse or the Poor Jews Temporary Shelter (Rozin 1999). A number of charities, including Manchester's Bread Meat and Coal Society (also known as the Poor Jews' Temporary Shelter), London's Jews' Temporary Shelter, and the soup kitchen resisted pressure from the Boards and strove to remain independent (Liedtke 1998; Rozin 1999).

In the early twentieth century, British Parliament considered imposing immigration restrictions, alarming the Jewish community. Ultimately the plans were watered down in the Aliens Act of 1905, which on the one hand regulated and restricted immigration, giving authorities the ability to turn away "undesirables" (those without the means of support, lunatics, and criminals), while allowing those who were escaping persecution to land. There was a slight decline in immigration following the Act through the start of the First World War, the hostilities of which halted much of the movement of civilians from Eastern Europe (Lipman 1954).

\section{Soup Kitchens}

At the end of the eighteenth century, war, stagnant trade, high unemployment, and bad harvests increased poverty and the price of food. Migration to the cities compounded the problems. Controlling and feeding the poor were perceived as major problems requiring novel solutions across much of Europe. In 1790, Benjamin Thompson, also known as Count von Rumford, set up a workhouse and a public kitchen on behalf of the Bavarian government, in order to deal with Munich's poor and beggars (Redlich 1971). Rumford-inspired soup kitchens sprang up in many northern European and American cities. Soup kitchens continued to proliferate during the nineteenth century. 
An 1887 pamphlet lists over 200 charitable institutions in London alone that served around 100,000 meals of cooked food daily to the local adult poor (Family Welfare Association 1887).

The upper classes may have favored soup kitchens as the solution to the poor's hunger because soup was a cheap alternative to bread whose price had increased dramatically. Efforts to reduce the cost of bread by using substitutes for wheat flour were unpopular, in part because it was adulterating a well-liked product. Sherman (2001) suggests that the promotion of soup was a cynical manipulation aimed at saving money and preventing unrest in the most economical way. Soup proselytes such as Rumford and Thomas Bernard were able to convince the better-off that a soup-based diet was more than adequate for the poor and that relief could be provided at a much lower cost than bread. They, along with Partick Colqhoun, a leading London magistrate and reformer, also thought that the poor might be reformed by exposure to cheaper foodstuffs and so learn to live frugally and become self-reliant (Colquhoun 1799; McQueen 1995).

The propaganda of soup may have assuaged upper-class guilt but the soup saved many from extreme hunger or starvation. Cash doles were seen as open to abuse; soup was not. Soup was cheap and relatively effective in providing nutrition. If the poor were given food "above their station" it would not only be more costly, it would act as a disincentive to work. The soup was probably sometimes on the borderline of palatability, despite the praises of the promoters, and the poor would have preferred something better. However, soup kitchens were a voluntary and charitable solution to hunger, not a state-supported intervention. The charities' records reveal their constantly-precarious financial condition; they could not have provided anything better if they wanted to. A charity that could be seen as encouraging the poor to rely on the generosity of others and even to prefer relief to work - would rapidly run out of donors.

However, soup as dietary reform met with only limited success; the poor preferred bread (Sherman 2001) while soup kitchens became an emergency stand-in. Soup may thus have had a coercive function: the poor were forced to adopt alternative means of feeding themselves if they could. Soup thus became a less eligibility test for food relief, situated just below the standard that a poor laborer would put up with if there was any alternative. In the middle decades of the nineteenth century, charities that aimed to relieve the poor adopted scientific charitable methods and investigated the circumstances of individuals to see if they were deserving before providing relief (Roberts 2004); this turned access to soup into a potential tool for influencing the morals of the poor. The COS further added to the emphasis of the coercive potential of withholding food to encourage reform, although the COS's philosophy did not meet with uniform approval on the part of middle-class participants in charities.

The majority of soup kitchens were ephemeral; many operated only during winter months (and then not every year) or in other times of severe hardship. They may be referred to once or twice in contemporary documents such as newspapers or charity publications before disappearing. Some have left more detailed records in the form of annual reports, minute books, and accounts, although these are often incomplete. Sometimes, it is not always clear whether a soup kitchen operating in one year is the same institution as one operating a decade later. The buildings used by soup kitchens were also short-lived; most have been destroyed by wartime bombing, urban redevelopment and slum clearance; the survivors have slipped into obscurity, having been 
converted to alternative uses. In England, only 11 buildings that once housed soup kitchens are "listed" (a form of legal protection for historic buildings); only about half of these buildings appear to have been purpose-built. It is not clear whether the examples discussed below are representative.

\section{The General Soup Kitchen, Newcastle}

\section{Documentary History}

Much of the information about the operation of the General Soup Kitchen is derived from the institution's unpublished minute books and accounts and other records held by the Tyne \& Wear Archives. The minute books contain a number of usually unreferenced newspaper cuttings relating to the institution's current activities.

It is uncertain exactly when the English soup kitchen that became known as Newcastle's General Soup Kitchen first opened. MacKenzie (1827) refers to a Newcastle soup kitchen operating in 1797 and 1798 and states that by 1800 the Town Corporation built a soup kitchen at the east end of the former poultry market. The Monthly Magazine (1800) refers to a revival of the soup kitchen taking place on November 14, 1799, suggesting that it was a subscription charity distributing soup free and that there were proposals to establish a separate subsidized institution for "those who might not wish to be considered as receiving gratuitous bounty" (Monthly Magazine 1800: 917). The kitchen operated only during winter months and does not seem to have been open every year.

There were other nineteenth-century soup kitchens in Newcastle, operated by parish churches and non-conformist chapels (no record of a Jewish soup kitchen in Newcastle has been found). During periods of high demand, caused by a combination of economic recessions and harsh winter weather, such as 1867-71 and 1875-80, the General Soup Kitchen operated two satellite kitchens in what were then industrial suburbs of Newcastle, Elswick/Scotswood to the west and Ouseburn to the north, and that it also occasionally provided schools and other soup kitchens with soup (General Soup Kitchen 1870, 1879, 1900).

The General Soup Kitchen opened daily except Sunday between mid-January or early February and the end of March in 1820, 1823, and 1827 (General Soup Kitchen 1867). Parson and White (1827) report that the soup kitchen was open only three days every week, selling 380 gal $(1,727.51)$ of soup daily at one penny per quart (1.1 1). This was below cost price; most contemporary soup kitchens sold subsidized soup which the poor could buy with their own money, with a token, or a combination of these.

There is a gap in the account book after April 1827 until March 1845, when the soup kitchen is described as having been "re-established" in premises at the Manors (a district of Newcastle) and that soup was offered for sale in January 1845 (General Soup Kitchen 1867). Evidence from local nineteenth century newspapers, not analyzed here, shows that the kitchen was operating in some of the years between 1827 and 1845, and furthermore the Town Corporation General Committees' minute book records that in February 1844, it gave the General Soup Kitchen $£ 20$ (the Corporation made further donations in 1847, 1848 and 1850) (Newcastle Corporation 1855). The kitchen probably moved to the Manors shortly before the poultry market, where it was 
originally located, was redeveloped in 1831 (Sykes 1833). Until it was relocated in the Manors police station (built in about 1836) in 1844/5, it seems to have been in William Holmes' premises in the Manors. The Manors had strong reformative presence. The 1831 Oliver map of Newcastle shows a building, marked as "Lock-up" next to the Holy Jesus Hospital, a row of seventeenth - century almshouses, in the space later occupied by the police station. Immediately behind the lock-up were the old house of correction and a charity school; just to the north were the poor house and town jail.

The minute books record very little about the police station which was located on the side of a hill. The building is shown on the first edition of the 1862 Ordnance Survey map for Newcastle. The soup kitchen seems to have used part of the lower ground floor (English usage is adopted here, with "ground floor" referring to the floor at ground level, and "first floor" to the level above that). It did not have a maze (a system of barriers to form the soup recipients into an orderly line) and distributions were sometimes chaotic. The Manors soup kitchen probably had between six and eight soup boilers as its daily maximum output was 500 gal (2,273 1) of soup. The payments made by the poor were vital to its finances and contributed about $40 \%$ of its operating budget.

The General Soup Kitchen was always closely linked to Newcastle Town Corporation. The mayor was usually chairman at committee meetings and many committee members were councilors; all were male. The Corporation regularly provided free premises for meetings and for the soup kitchen itself, first in the Corporationowned disused poultry market from 1797 to circa 1831 and then in the police station (also owned by the Corporation) from the mid-1830s to 1879. In 1880 the Corporation gave the soup kitchen land for its new building. In addition, the Corporation made fairly regular donations to the soup kitchen funds, as did the committee members. John Thompson, the Corporation's architect and engineer, designed the new 1880 building and supervised the construction gratis. The informal involvement of the local authorities seems fairly typical of many English soup kitchens, in contrast to contemporary French and German institutions which were often formally managed by the authorities (Redlich 1971).

The kitchen operated only during the winter when the weather was considered sufficiently bad to be causing the poor distress. Bad weather was the only reason given for opening, and as soon as the bad weather was over, it was closed. On several occasions, a sudden snow storm obliged the committee to reopen or postpone a planned closure. Hard times in and of themselves were not sufficient reasons for opening the kitchen. There were often delays of several days between the committee's decision to open and the opening itself. In late December 1870, when severe winter weather resulted in high unemployment, the committee even expressed "some regret" at not having opened the kitchen sooner. An engineers' strike in March 1892 resulted in considerable debate as to whether the kitchen should open. Initially the committee considered deferring the decision on opening to the Poor Law Guardians as it had done in a previous strike in 1888. In the end it did decide to open, swayed by the large numbers of poor who were affected by the strike but not engaged in it.

The kitchen served soup from 8 am until it ran out or midday, six days a week; it was closed on Sundays and usually on Christmas day. The soup was beef-based with peas, barley, and rice in smaller quantities, and seasoned with salt and pepper. After 1866, carrots, parsnips, and celery were added on the suggestion of the local prison governor. The recipe is similar to those published 
by other soup kitchens. There is nothing recorded in the minutes about any concerns about the quality of ingredients.

When the police station was demolished in 1879 to make way for a new school, the committee, assisted by the City Corporation, built a new soup kitchen on a small plot of land adjoining the Holy Jesus Hospital (the "Hospital") across a narrow courtyard from the school (Fig. 3). It opened in 1880 at a cost of around $£ 900$ (the land was free). From 1881 the Discharged Prisoners Aid Society used the upper floor of the building outside the winter months as a temporary laundry in which female ex-convicts could find work on their release from the nearby prison.

During the 1870 s and 1880 s, the committee appears to have adopted a harsher regime. The soup kitchen opened far less frequently than before. Between 1851/2 and $1867 / 8$ it opened every winter. Between the winters of $1868 / 9$ and $1880 / 1$ it was open eight out of 13 winters, but between 1881/2 and 1891/2 it was only open four winters out of ten. The minutes suggest that the committee was only too keen to close it, despite other charities wanting to use the facilities to prepare food for the poor. On several occasions during the 1870 s, requests for bread to be served on Fridays to Catholics, who could not eat beef for religious scruples, were rejected by the committee. In 1879 and again in 1881, the committee rejected suggestions that soup be served free of charge because "it would promote great dissatisfaction amongst the recipients of the soup" (it is doubtful whether the committee actually canvassed any opinions other than their own on this point). Soup production was lowered to about 200 gal (909 1) a day. In 1892, the committee rejected an offer from a baker to supply the kitchen with bread at cost price.

There was still enough local support to finance half of the cost of the new building but subscriptions barely covered the cost of serving half the volume of soup that had been served in the past. In February 1888 the kitchen had insufficient supplies and was turning away the poor as a consequence. A press cutting in the minute book criticized the kitchen for not providing Catholics with Lenten-compliant food. The committee

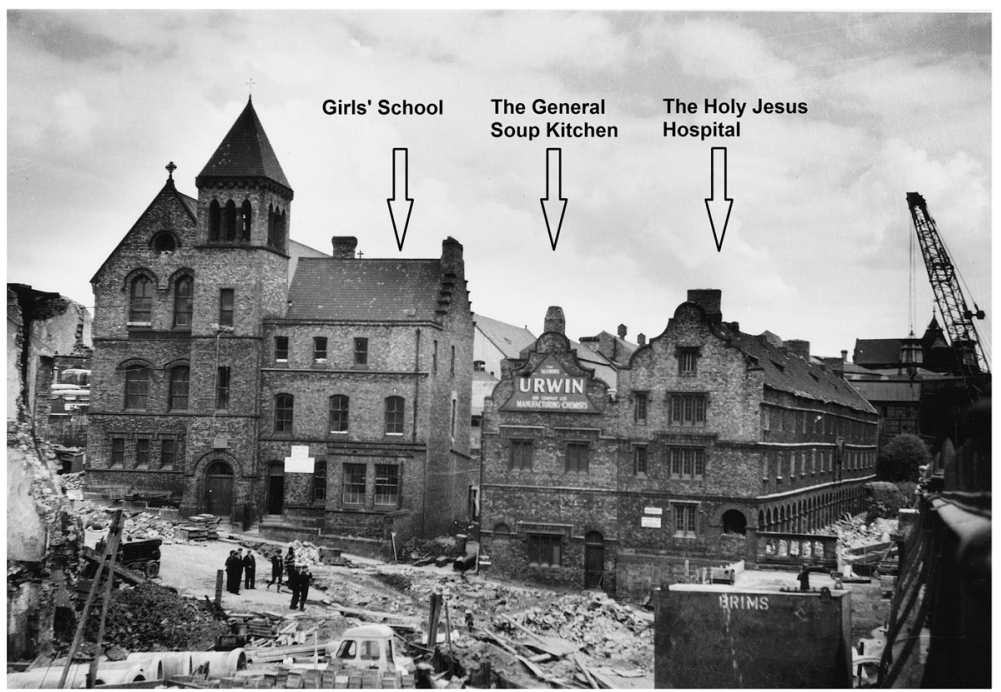

Fig. 3 The General Soup Kitchen and Holy Jesus Hospital during road construction ca. 1962 (photo by Jimmy Forsyth, courtesy of Tyne and Wear Archives, Newcastle) 
decided not to open in 1891 because the Poor Law Guardians and police superintendents had reassured the committee that most of the current poverty was due to drink.

Declining subscriptions and the unwillingness to provide relief coincided with the crusade against outdoor relief. The charity was not fully independent from political influence. The new kitchen had been completed at a time when people were questioning whether providing the poor with food was worthwhile. The Society for the Organisation of Charitable Relief and Repressing Mendicity in Newcastle (a branch of the COS) seems to have begun exerting an influence; it had approached the committee in 1880 wanting to use the first floor of the building. In 1887, the soup tickets were not given to subscribers, but handed directly to the COS and the district relieving officers for distribution, because they "knew better." In 1892 when the Labourers' Union asked for representation on the committee because it was familiar with the poor, the committee rebuffed them.

After 1885 , the committee considered permanently closing the kitchen on several occasions. They decided to close for good in 1892 and to dispose of the equipment and money on the grounds of abuse of the kitchen by "people at the bottom of Pilgrim Street [who] had for weeks together kept their lodgers with the soup from the soup kitchen" (General Soup Kitchen 1900, entry for March 11, 1892). The committee declined to investigate the alleged abuse, and, despite the planned closure, opened, stating that children without tickets were not to be turned away without soup. Within $45 \mathrm{~min}$, the 200 gal (929 1) of soup that had been prepared were gone. The story of the local lodging houses selling on the soup to their lodgers as "something special" was repeated at an 1893 meeting to decide to close the kitchen, despite the same minutes recording that the kitchen had not been open for the previous 12 months. The committee argued that although the kitchen had done useful work in the past, the need did not exist anymore; nevertheless, it distributed its assets to other charities that included three soup kitchens (General Soup Kitchen 1900, entries for March 15 and 28, 1893).

The kitchen was closed for good in March 1893 and the ground floor was rented to a pork butcher. The Discharged Prisoners Aid Society continued to use the first floor until the entire premises were handed back to the Corporation in 1900. It was then used as a factory. When the Hospital closed in 1937, it and the soup kitchen space remained vacant for many years. The building re-opened in 1971 as the Joicey Museum following major refurbishment. The building and the adjoining Hospital are currently listed by English Heritage and are cared for by the National Trust, which uses them as a museum, offices, and storage.

\section{The Building}

The present building has several variations from the original design held by Tyne \& Wear Archives (Newcastle Corporation 1879). The exterior walls have been repointed several times, making it difficult to see alterations. Only two photographs of the building taken before 1960 are known; neither are sufficiently clear to aid in interpreting the building. The City Library, Newcastle, holds several photographs taken between 1962 and 1965 during road construction, including Fig. 3. There is a contemporary drawing of the west façade of the building and the Hospital (Architectural Association 1891) although the drawing does not seem to be entirely accurate. Figures 4 and 5 and the description below combine information from the author's 

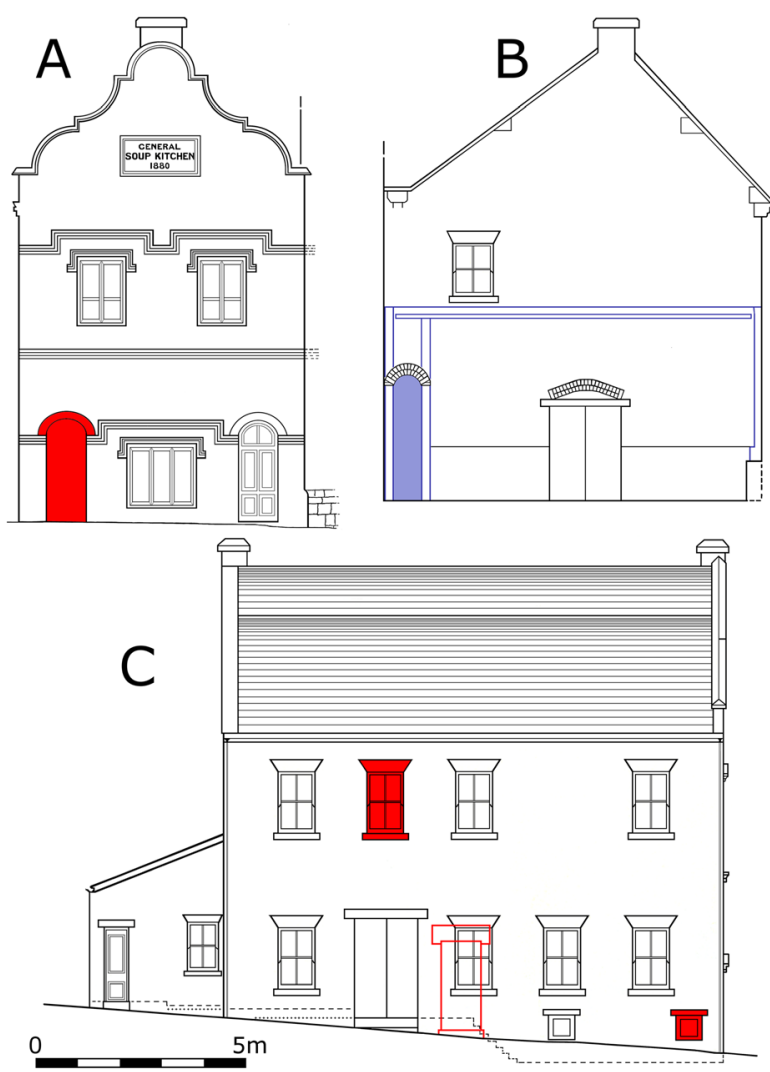

Fig. 4 Newcastle General Soup Kitchen elevations based on 2014 survey and 1879 designs; A west, B east and C north; A and C show 1893 alterations shaded, B shows 1960s alterations and traces of lean-to shaded (drawings: author)

survey with information from the original design and minute books to reconstruct what the kitchen would have been like when it was operational.

The building is a wedge-shaped trapezium in plan with the longer sides oriented west-east; it is two stories high. Its total floor area at the time it was a soup kitchen was about $250 \mathrm{~m}^{2}\left(2690 \mathrm{ft}^{2}\right)$. The ground floor has two levels: the west half is about $1 \mathrm{~m}$ ( $3 \mathrm{ft}$ ) below the east half in order to accommodate the site's slope; the first floor is built on one level. The "front" of the building (the west wall) faces what was Manors Chare to the west. This façade is now virtually inaccessible as it is only about $0.3 \mathrm{~m} \mathrm{(1 \textrm {ft } )}$ away from the wall enclosing the A167M road below and the A186 roundabout and road bridge above.

The west wall has arched doorways on either side of a central stone window, which has three lights separated by chamfered mullions (Fig. 4). The window's lintel forms a hood molding. Both doorways are now blocked with brickwork. The northern door does not appear in the architect's design or on the 1891 drawing and was probably added in 1893 to provide access to the boiler without going through the butcher's shop. The mortar joints are wider and the voussoirs in its arch are not as well-shaped as the southern doorway. 


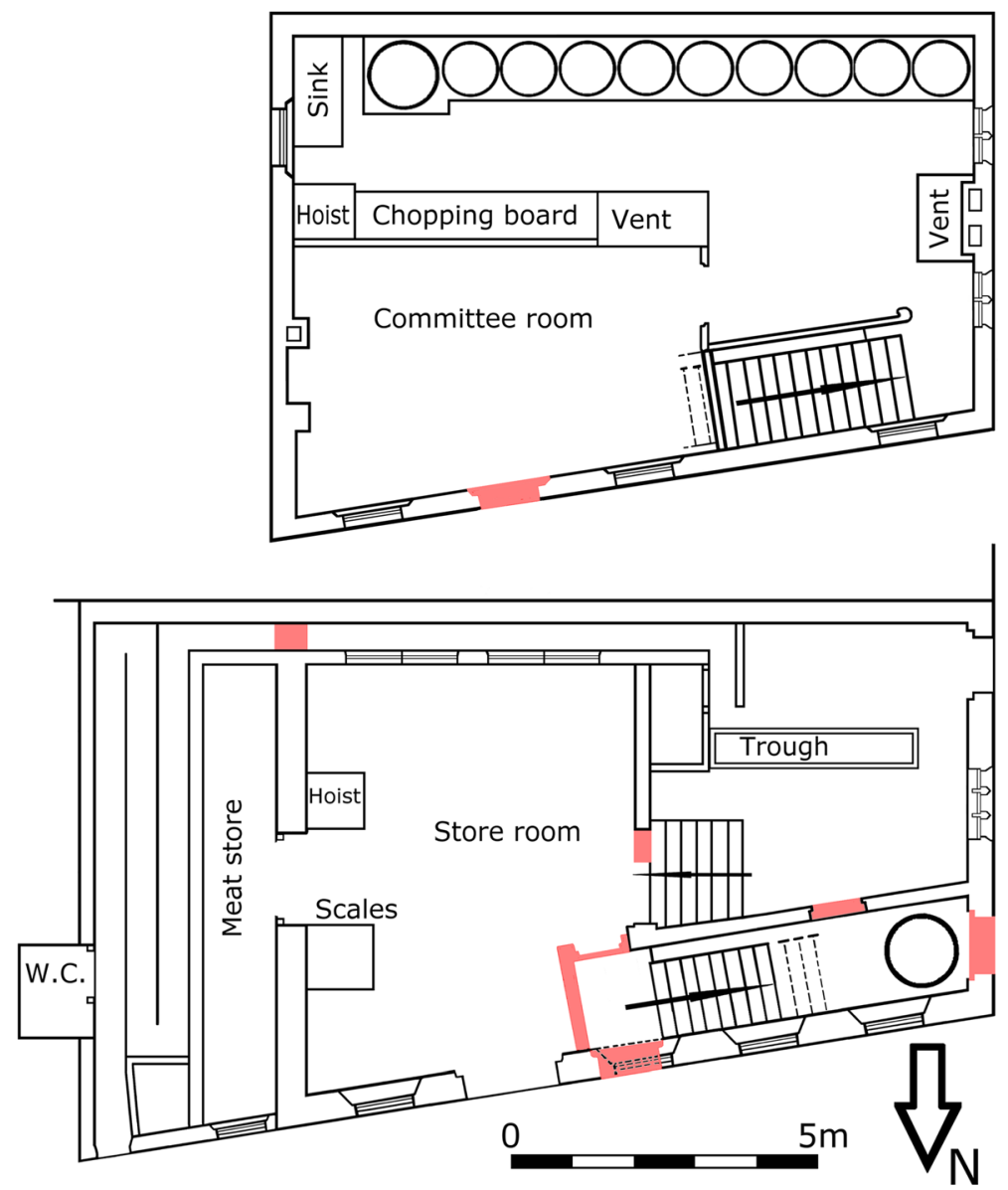

Fig. 5 Newcastle General Soup Kitchen plans of the first floor (above) and the ground floor (below) based on the author's survey and the original designs; 1893 alterations are shown shaded (drawings: author)

At first floor level, a pair of stone two-light mullioned windows are topped by a Dutch gable with a date stone carved "GENERAL SOUP KITCHEN 1880" in relief. Simple decorative stringcourses of red brick run level with the tops of the doors, at first floor level and over the first floor windows. The brickwork, hoods, string courses, and Dutch gable reflect the style of the adjoining seventeenth-century Hospital. The south wall abuts the north wall of the Hospital but is independent of it.

The brickwork on the north wall uses a plain garden wall bond. There are one wide doorway and one ordinary-sized door next to it, and three large windows and two small windows level with the street at ground floor level. At first floor level there are four large windows. All the windows and doors on this wall have stone lintels and sills. The ground floor windows are now blocked up, but the first floor windows contain balanced sashes. The ordinary-sized door, one of the ground-level windows and one first floor window do not appear on the original design, which called for a window roughly where the additional, circa 1893 northern door is. The lintel over this door has a different shape and proportions from the other lintels in this wall. 
The design shows a single story lean-to with a small window and narrow doorway on its north wall adjoining the east end of the present building. Evidence for the former lean-to is visible in the existing east wall of the soup kitchen which still contains a timber roof plate that would have supported the rafters of the roof of the lean-to (Fig. 6). Above the plate, a line of tar staining and a wider mortar joint show where the roof and its flashing would have met the east wall. Differential exposure to weather and pollution has left the brickwork that was once inside the lean-to and in the sheltered part of the Hospital's north wall lighter in color. The brickwork at the corners of the east wall shows signs of repair where the lean-to walls would have joined. The Ordnance Survey map from the 1880 s shows the lean-to, but it is unclear if the privy/water closet shown on the design projecting from its east wall was extant. The lean-to was probably demolished when the Joicey Museum was established in 1971.

The ground floor part of the present east wall would therefore originally have been an interior wall. The lower $1.2 \mathrm{~m}(3.9 \mathrm{ft})$ is built of brown - glazed brick. A tall narrow doorway with a semi-circular arch against the join with the Hospital wall has been blocked, probably in 1893. In the center of the wall is a pair of double doors. At first floor level there is a single window. The gable is a plain irregular triangle with the chimney and the ridge of the roof is off-center to keep the ridge parallel to the north wall. The roof is tiled with dark grey slate and has a louver near the ridge, running the length of the roof on both sides.

\section{The Interior}

Raw ingredients entered the building through the large double doors in the north wall. Meat would have gone into the meat store that the design shows in the lean-to, via the double doors on the east side (Fig. 5). The meat store was lit and ventilated by a small north-facing window; its glazed brick and the north easterly aspect helped keep it cool. Other ingredients would have been kept in the store room. When required in the

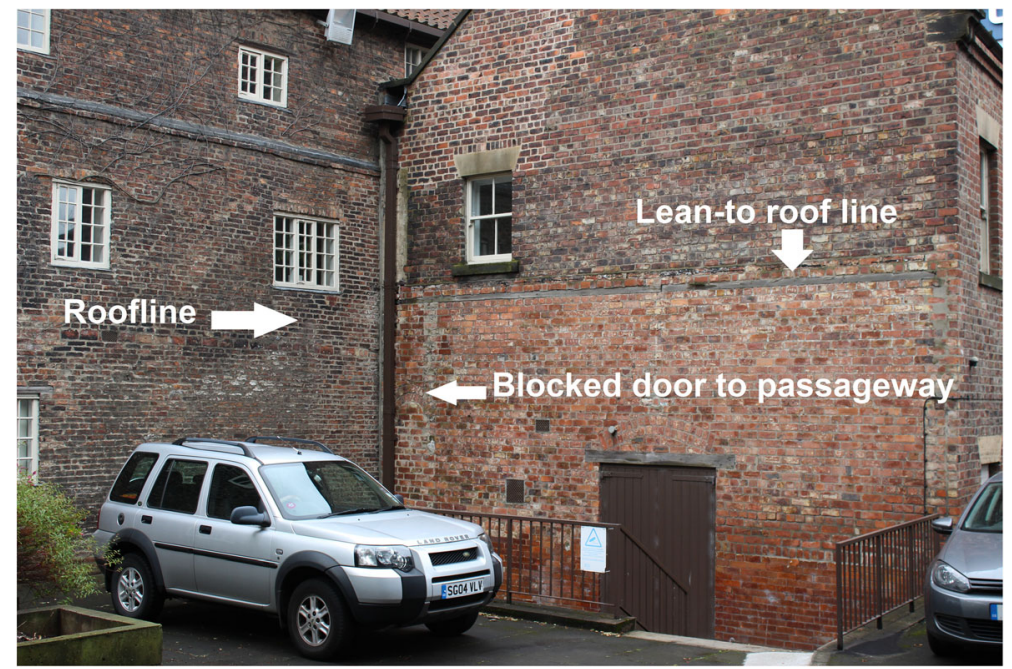

Fig. 6 Photo of east wall of General Soup Kitchen showing traces of former lean-to roof and blocked passageway (photo: author 2014) 
kitchen, ingredients could be weighed and sent directly up to the first floor by a hoist (a weighing machine and hoist appear in the design and are listed in the building accounts). A stair-lift up to the kitchen, probably a cart on rails with counterweights and pulleys, was also available at the west end of the building; the slot beside the banisters for the counterweights still survives as does the anchor point for the pulleys. The stair-lift is not shown in the design although the extra-wide staircase is; if it is a later alteration it would have required the construction of an entirely new stair. The store room is on a higher level than the boiler room and serving area at the front of the building; they are reached by a flight of six stone steps in the center of the building. The internal partition that separates the staircase from the store room is probably an 1893 addition and the door in it an ever later alteration; neither are shown in the original design.

The boiler room was located at the front of the building in the northwest corner, where the original chimney still survives. Coal might have entered through the store room door or through a chute in one of the small windows at ground level. Steam generated by the boiler would have been piped up to the kitchen on the first floor for heating the soup. By the second half of the nineteenth century, steam-heated soup boilers were in common use. An undated handbill advertising the kitchen states that the soup was superior because it was steam-heated (Baglee 1971).

The kitchen on the first floor had windows on three sides. The hoist delivered ingredients directly to the area next to the chopping board and sink in the northeast part of the kitchen. The prepared ingredients progressed from there to a digester (an enormous pressure cooker) and a row of soup boilers (the design shows nine boilers, but the accounts record that six were installed). Each would have had a capacity of 80 to 100 gal (364-455 1). The soup would have been cooked overnight. The leftover bones from the cooking were sold in bulk to local chemical factories. The kitchen was open to the roof (the trusses and wooden lining to the inside of the rafters are planed and painted timber) allowing ventilation through the louver. There were also two ventilating flues shown on the original design.

According to a press cutting in the minute books, the finished soup went down a pipe into a trough in the ground floor serving area. Three drawings of a soup kitchen in Manchester from 1862 (Fig. 7) show a similar arrangement with a digester and soup boilers, presumably on the first floor of a building, and large pipes emptying into a long trough on the ground floor (Illustrated London News 1862). This technology enabled a small site to generate large amounts of soup efficiently.

Crowds were waiting outside at 8 am for the kitchen to open as the volume of soup made each day was finite. According to an 1881 press cutting in the minute book, the people held "all sorts of pots including chamber pails, American beef tins and washups" to transport the soup away. Less soup was made on the first day of the season as word about the kitchen opening or the precious tickets might not have got through to everyone. Demand on Mondays was also lower either because some people had a little money left from the previous week or because a little more casual work was available to people at the start of the week.

To enter the soup kitchen recipients of soup used a narrow door about $0.6 \mathrm{~m} \mathrm{(2 \textrm {ft } )}$ wide in the lean-to, not what appears to be the main door in the west façade (see Figs. 4 and 5). On entry, they would have had to pass a small cubicle, where, based on plans from early nineteenth-century soup kitchens (e.g., Colquhoun 1799), the ticket entitling them to soup was checked. They could only get soup tickets as a personal gift from a 


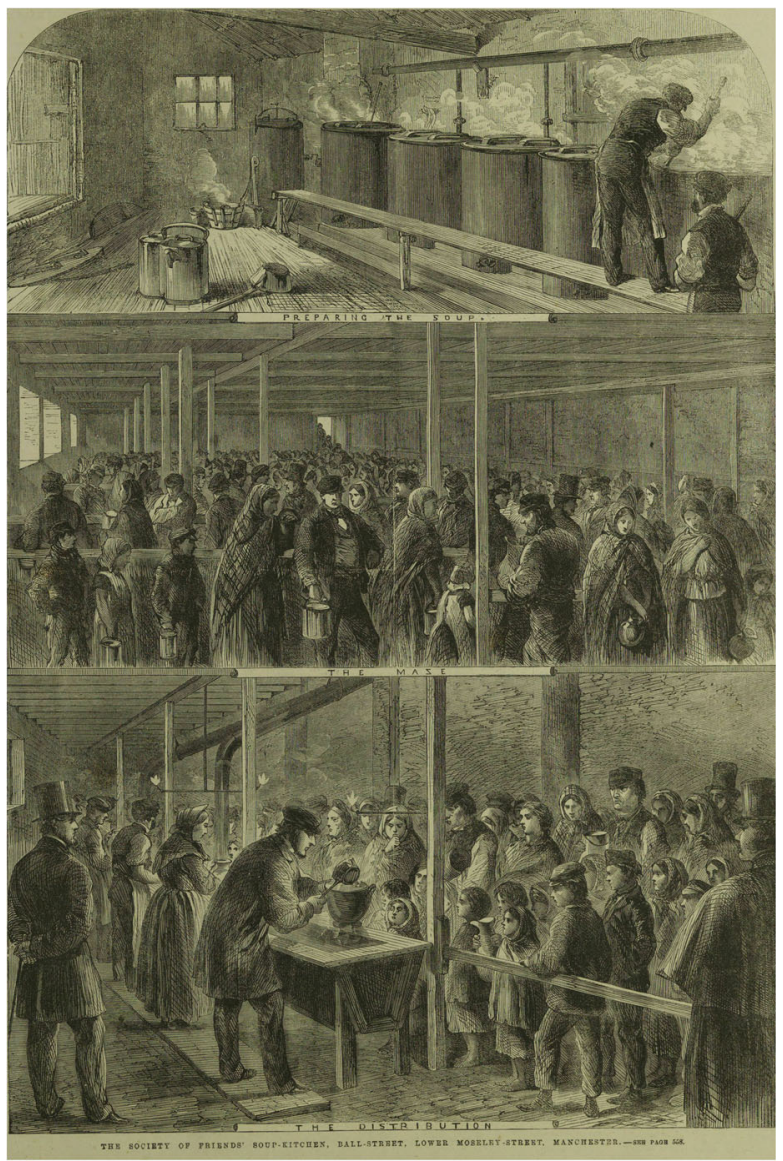

Fig. 7 The Society of Friends Soup Kitchen, Ball Street, Lower Mosely Street, Manchester (Illustrated London News1862)

subscriber or from a committee member or a parish vestryman. Even with a ticket, they had to pay a half penny per pint. Anyone without a ticket would have to wait until all the ticket holders had been served, and then pay a penny per pint. Part of a surviving ticket is pasted into the minute book for 1870-79; the thick pink paper is printed with at least four rows of six squares each with a letter; presumably each row represented an individual's week's entitlement to soup.

After having their tickets checked, the recipients entered the maze, where, although they were at least sheltered from the weather, they were still $20 \mathrm{~min}$ of slow shuffling away from a meal. All that could be smelled at this stage would be other people in the queue or the small privy or water closet located just inside the entrance to the maze; there were no facilities to wash. The maze was only $0.45 \mathrm{~m}$ (18 in.) wide and each length was separated from the next part by a waist-high barrier. People were densely packed, creating an even higher human barrier. When the soup kitchen was first opened, several of the better-fed members of the committee had "difficulty threading the maze" which was specially designed for "thin persons." Figure 7 shows a wider maze in operation. Mazes were used by soup kitchens from the 1790 s onwards to 
control crowds. There probably was not a maze at the old police station as a newspaper cutting from 1888 refers to the new building's maze and states that "the scenes witnessed at the old place do not take place" (Minute Book, February 1888).

After three turns through the maze, recipients entered a long and narrow passage through the now-blocked door in the east wall (see Fig. 6). The passage was marginally wider than the maze at $0.51 \mathrm{~m}$ (20 in). The walls extended on either side to ceiling (about $10 \mathrm{ft}$ or $3.3 \mathrm{~m}$ above); four windows in the north wall, above head height, allowed some light in from the store room. The south wall of the passage has a glazed brick dado; the north wall has been demolished, probably in 1893. The maze and passage would have been dark, cold, damp, and claustrophobic. Steps were probably used to negotiate the drop to the serving area which would have been hazardous in the gloomy, crowded passage. The kitchen had gas lights (bills are recorded in the accounts) so the maze and passage may have had some artificial light; neither was heated. The maze was about $22 \mathrm{~m}(72 \mathrm{ft})$ long and the passage was a further $7 \mathrm{~m}(23 \mathrm{ft})$ long, accommodating between 50 and 70 people at any one time. On a busy day, the kitchen served 500 gal $(2,273$ 1) of soup in four hours to between 800 and 1000 people; the majority had to wait outside in the courtyard for some time.

By the time they could smell the soup and see daylight, recipients were almost out of the passage and into the serving area but first passed another cubicle, where they probably handed over their tickets and money. One of the assistants ladled soup from the trough into the waiting crockery and then the recipients were out on the street via the door in the west façade. The trough shown in the design was much shorter than that shown in Fig. 7.

The committee room on the first floor was much more comfortable. It was the only room to have fully plastered walls and a fireplace. The room had three windows opening onto the courtyard below which would have allowed the committee, which met once a week during kitchen opening hours, to view the queue. The room was certainly pleasant enough for other organizations to want to use it.

Overall, the building is austere. The Dutch gable, hooded windows, and chamfered mullions are conservative features for a late-Victorian building and hark back to a more romantic past when charity was more paternalistic and less industrial. The north wall has no ornamentation and could be mistaken for a house except for the large double doors. The interior is purely functional and every expense was spared in construction, unless it made soup production and distribution more efficient. Growing unease over indiscriminate charity seems to have prevented any effort to make the building pleasant or comfortable.

For the poor, visiting the kitchen cannot have been pleasant or comfortable. They had to approach the building from the narrow courtyard at the side, hidden from the outside world, using the smallest, most remote door. Once inside, they were subject to inspection and herded through a maze so narrow that they had to be genuinely malnourished to fit. The rational efficiency and inspection of credentials imposed order and discipline. If anyone was late, the soup was gone, so to make sure they got some, people had to arrive early and wait in the cold; after all, they had nothing better to do. The mechanical systems and sheer numbers of poor moved through the soup kitchen depersonalized the whole procedure of serving food, as each person had to be served as quickly as possible. 


\section{The Soup Kitchen for the Jewish Poor, London}

\section{Documentary History}

A Jewish soup kitchen was established in London in the late-eighteenth century, "a few years after" Levi Cohen, the warden of the Great Synagogue, established Meshebat Nephesh, a bread, meat, and coal society in 1779 (Hyamson 1908). Several of the charity's meetings were held in the "Soup House, Mitre Court, Duke's Place" (Wolf 1934); Duke's Place was also the location of the Great Synagogue, so it is very probable that this soup house was the "Kosher soup establishment" that is recorded as operating in 1800 under the presidency of Benjamin Goldsmid (Stein 1959). The Jewish Year Book ( 1907) credits the Goldsmid brothers and Cohen and Joshua van Oven as founding a soup kitchen. The Goldsmid brothers were wealthy bankers active in both Jewish and non-Jewish charities; Joshua van Oven was the medical officer to the poor of the Great Synagogue, and all had been presidents of Meshabat Nephesh and involved in the van Oven scheme. This is also almost certainly the soup kitchen referred to as the "Jewish Nation Soup Committee" that was feeding 900 daily in early 1800 in a list of over 40 soup kitchens then operating in London (General Report 1800). This kitchen received support (along with many of London's other soup kitchens) from the Lloyd's Coffee House Committee, a group of wealthy, mostly Christian, philanthropists based in the City (the central district of London) (General Report 1800).

These Jewish food charities were Ashkenazi-sponsored; the Sephardic community was smaller and had been developing its own charities since the early eighteenth century, whereas the Ashkenazi community seems to have been much slower in coming to the aid of its poor (Wolf 1934). Levi Cohen is quoted as saying that the soup kitchen would not have survived but for the Christian benevolence of the Lloyd's Coffee House Committee (Cohen 1943). The Ashkenazi community seems to have adopted a very English approach to philanthropy, modelling the soup kitchen on contemporary English soup kitchens rather than following strictly Jewish precedents (Stein 1959). This is evidenced by the soup kitchen being a subscription charity and selling the soup at one penny per quart (General Report 1800), rather than giving it away. The use of English precedent is perhaps unsurprising given the connections between people like Cohen, Goldsmid, and van Oven with English welfare experts such as Patrick Colquhoun and the Lloyd's Committee, who provided them with advice and resources.

The next reference to a Jewish soup kitchen in London is in March 1854, when the Jewish Chronicle appealed for funds for the Soup Kitchen for the Jewish Poor to serve the newly arrived Polish Jews (Endelman 2002); it was situated at 31 Leman-Street, Whitechapel (Jewish Year Book 1907). In 1856, it moved to Black Lion Yard assisting about 5000 people of a total Jewish community of about 28,000 (Lipman 1959). Magnus (1909) refers to the soup kitchen premises being in Black Horse Yard. In the winter of 1866/7 the kitchen moved to Fashion Street. In 1902, the soup kitchen moved to purpose-built premises in nearby Butler Street (renamed Brune Street in 1937) (Soup Kitchen for the Jewish Poor 1889c). The gradual migration of the kitchen, eastwards and then northwards, followed the development of the Jewish East End (see Fig. 2).

Much of the information about the operation of the Soup Kitchen for the Jewish Poor is derived from the institution's unpublished minute books and accounts and other 
records held by the Metropolitan Archives, London. From at least as early as 1872, the kitchen served both soup and bread to its clientele (Soup Kitchen for the Jewish Poor 1889a, 1889b). The soup used typical ingredients, including cheap cuts of beef, peas, barley, rice, and vegetables. In addition, the kitchen provided special supplies at Passover, including coffee, sugar, and matzo flour. The committee regularly checked samples of the bread (once having it analyzed) and investigated complaints about short deliveries and the quality of the meat. The Soup Kitchen for the Jewish Poor was open three days a week, from mid to late-December until early April, around the time of Passover, at 5:30 pm, except on Fridays when it was open from 11 am to $2 \mathrm{pm}$ to enable closing before the start of the Sabbath which in winter would have been $4 \mathrm{pm}$. In the 1890 s it often opened five nights each week. From the 1870s through the end of the 1880s, the kitchen served about 650 individuals daily (numbers declined slightly in the mid-1870s). The minute books report that numbers increased $10 \%$ annually in each of the first four winters of 1890 s “owing to immigration of our foreign poor;" by 1900/1 the kitchen was serving 2200 portions each day and by 1905 over 1600 families (about 8000 individuals) were being supported by the soup kitchen (Soup Kitchen for the Jewish Poor 1889b).

The institution was wholly financed by subscribers, bequests and fund-raising events. The committee was all male but women carried out a lot of the fund-raising; some committee members attended distributions. The soup and bread were given free to the poor. In 1873 when Lady Rothschild, a regular donor, suggested that the soup kitchen start charging the poor one penny for their soup (standard practice in English soup kitchens but not at the Soup Kitchen for the Jewish Poor), the committee politely declined her proposal (Soup Kitchen for the Jewish Poor 1889a). Around 1890 it started the practice of giving special distributions to the poor in the name of a sponsoring benefactor to mark particular family events (Jewish Year Book 1907), thus reintroducing a more personal relationship with echoes of traditional paternalism.

The Soup Kitchen for the Jewish Poor provided its clientele with soup cans whose size varied according to the size of the family they were supposed to feed. In 1892 the kitchen had 600 cans but had to order another 500 to accommodate the growing numbers of poor, especially recent immigrants (Soup Kitchen for the Jewish Poor 1907). The minutes also refer to the printing of tickets which may have been used by "casuals" (those not registered for long-term relief) or if there were insufficient cans. Figure 9 shows cans in use in the Fashion Street and Butler Street kitchens (also see Fig. 12). Cans had several advantages over the range of broken crockery used by the English poor to collect their soup: they acted instead of tickets, they were unbreakable, they ensured the correct measure of soup was given, and importantly, they ensured dietary laws were complied with (Jewish dietary laws prohibit the same container being used for meat and dairy products). The kitchen also provided food to non-Jews (Illustrated London News 1879).

The staff operating the kitchen included a cook, a porger (whose job was to remove fat and blood vessels from the meat in accordance with dietary laws), a number of assistants, and a superintendent. The fat and left-over bones were sold. The accounts also record an allowance paid to the police for attending distributions to ensure good order, possibly evidence of the absence of a maze. Until the move to Butler Street, the committee meetings were usually held in rooms rented from the Board of Guardians, although occasionally the committee met at Fashion Street. 
The Jewish Year book (1907) records that the soup kitchen abandoned "indiscriminate distributions" in 1874, implying that it had practiced this before. In fact what happened was a bit more complicated. The committee had its own investigating officer, but, concerned that it was providing relief to some who were also receiving relief from other Jewish agencies, the committee asked to see the London Board's list of those receiving Passover relief. The Board responded that they did not have the resources to provide a copy, but that the two bodies should co-operate to stop "imposition." The committee agreed to provide a list of applicants for the season to the Board who would then mark up this list showing those whom it was then assisting (the list was already available to subscribers). The committee could then act as it felt appropriate. The names of casuals and later additions to the roster would be handed over one or two times a season. This action corresponds with a $15 \%$ reduction in the number of portions served for the next two years, although the trend was already downward, so there may be other reasons for the decrease. Any one committee member could grant immediate relief if they saw fit, but relief could only be stopped if two committee members decided the person was undeserving. With 700 applicants at the start of the season, it would be surprising if the investigation was meticulous; identifying those who had not been in England for six months (the Board of Guardians' publicized criteria for relief) would have been difficult. In 1897 the committee increased the size of their investigating committee in response to "an organised imposition" that had been reported in the Jewish Press. In 1898, the minute books record that only 11 of 1045 applications were refused; the figures for 1899 were similar.

The soup kitchen continued in operation through the Second World War (when it distributed food parcels only) and closed in 1991. The charity itself continues in existence as "Jewish Care" (Jewish Care 2015).

\section{Fashion Street}

The Fashion Street building is shown on the first edition of the Ordnance Survey map of London (ca. 1867-70) and is marked as "Jews' Soup Kitchen." The building was situated in a large courtyard behind Fashion Street, accessed only by a covered cartway. It abutted other buildings on three sides (Fig. 8). The rectangular building had two projecting wings and a floor area of roughly $110 \mathrm{~m}^{2}$ (about $1180 \mathrm{ft}^{2}$ ); it was probably a single story. The 1897 edition of the Ordnance Survey map shows a small addition on the eastern wing which may be an additional privy or water closet built by the committee in 1875 . It was probably formerly a workshop or stable block, not purpose-built. It was whitewashed with shutters on the windows, gas lights and coppers (soup boilers), and a boiler to produce steam. The kitchen probably had eight or more soup boilers to produce the volume of soup recorded. There were problems with steam and poor ventilation.

The only known picture of the Fashion Street soup kitchen is of the interior (Fig. 9) (Illustrated London News 1879). The picture shows a gas-lit room with soup boilers at the back and a meat store to one side. One of the cooks, standing on a block to reach into the boiler, ladles the soup directly into a man's can; many of the clientele have cans and there is a long wooden table where one man sits eating his soup and bread. There is no sign of a maze; the yard may have been used to organize the crowd. Bearing in mind the building is less than half the size of the Newcastle soup kitchen, it must have been cramped. Even before the lease expired, the committee was aware of the limitations of the building. 


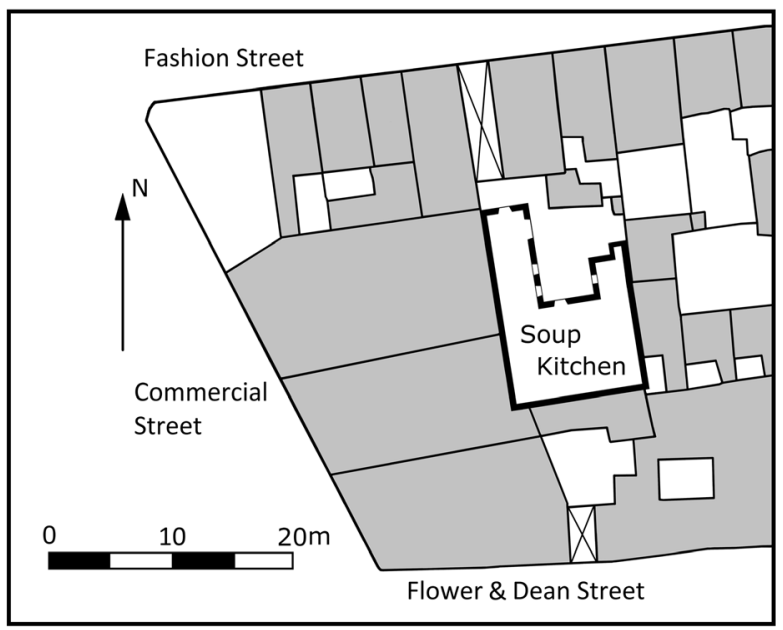

Fig. 8 Plan and location of the Soup Kitchen for the Jewish Poor, Fashion Street ca. 1873-1902 (drawing: author)

\section{Butler Street}

In 1902, the committee had a new kitchen built on nearby Butler Street (now renamed Brune Street). Designed by Lewis Solomon, a leading Jewish architect (Fraser 1996), the four-story building occupies over $21 \mathrm{~m}(69 \mathrm{ft})$ of street frontage. The ground floor terracotta ornamentation displays the building's title "WAY OUT SOUP KITCHEN 56621902 FOR THE JEWISH POOR WAY IN" with a tureen of soup against a scalloped background over the central door (Fig. 10). The dates are the Jewish and Christian eras respectively. The upper floors are classically inspired, divided by pilasters and terracotta mullions with ornate brick arches, pediments, and a Diocletian window to the top floor (Builder 1903).

Only the ground floor was used for the soup kitchen. The upper floors, basement, and a shop to the side were rented out to tenants to generate income for the charity. The soup kitchen floor area was about $260 \mathrm{~m}^{2}\left(2800 \mathrm{ft}^{2}\right)$ (Fig. 11), far larger than the Fashion Street premises but comparable to Newcastle. To get soup, recipients would

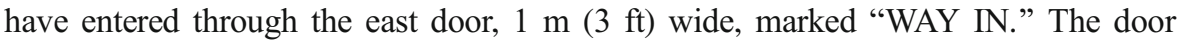
opened into the waiting room where the maze started. The maze was $0.7 \mathrm{~m}(2.3 \mathrm{ft})$ wide (significantly wider than Newcastle), about $40 \mathrm{~m}$ (131 ft) long and, according to the architect, capable of holding 100 people. The room had a large south-facing window, a fireplace, and electric lighting. At the end of the maze a small window was probably where recipients' entitlement to soup was checked. They then entered the kitchen and serving area in the rear of the building. This was one story high, ventilated by hoods and vents over the boilers and a lantern in the roof (Fig. 11). The kitchen had marble work surfaces, nine 60-gal (273 1) soup boilers and a large digester on either side of the door to the meat store, as well as a bread store capable of holding 1.5 tons of bread. Coal for the boiler that heated the soup was stored in a cellar below. The serving area consisted

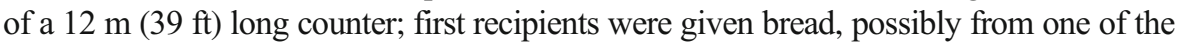
lady visitors who assisted at the kitchen and then soup from one of the uniformed kitchen assistants. They exited from the west door. There were separate male and 


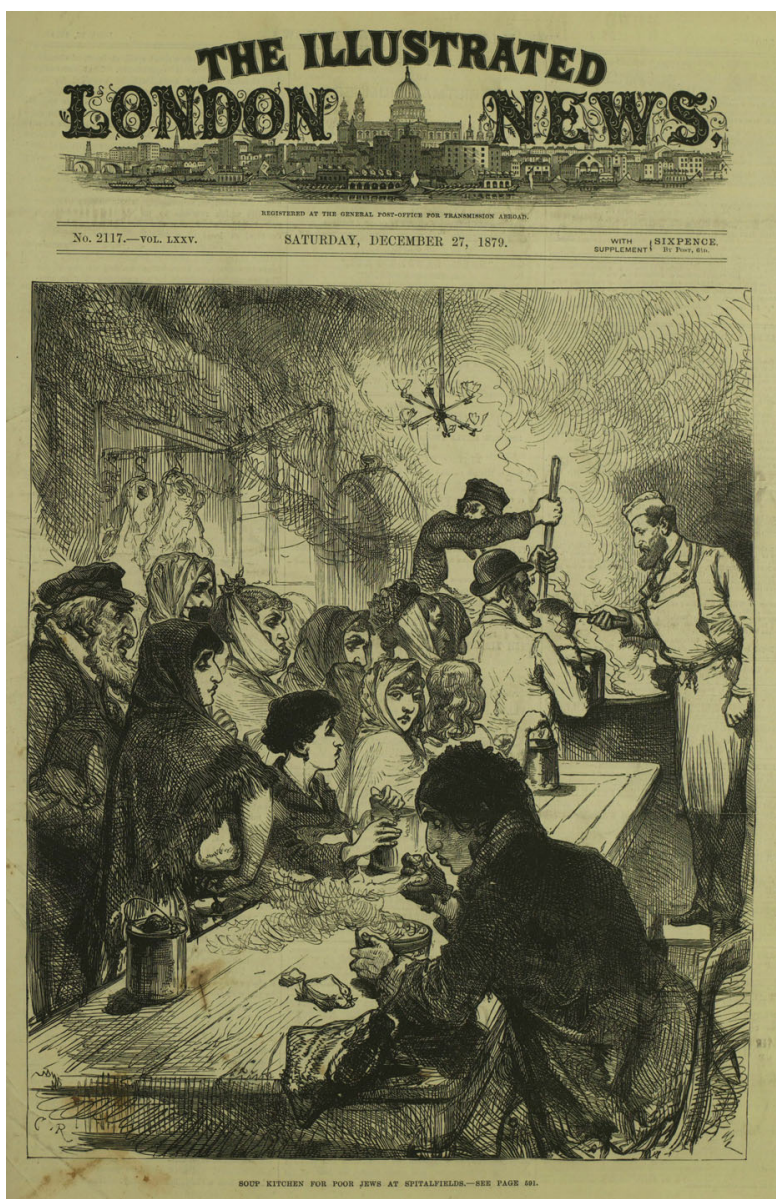

Fig. 9 The Soup Kitchen for the Poor Jews in 1879 (Illustrated London News 1879)

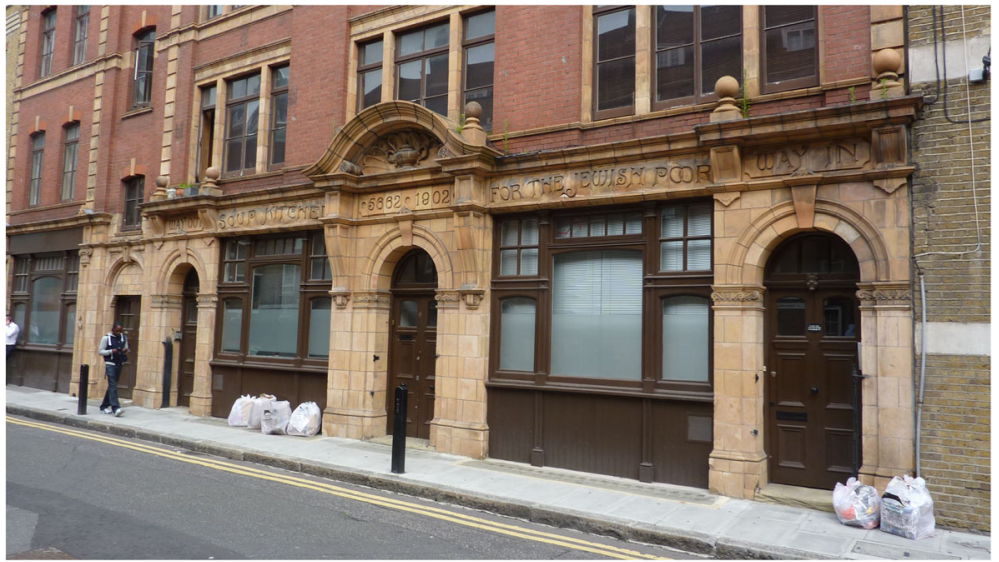

Fig. 10 The Soup Kitchen for the Jewish Poor, Butler Street, London (photo: author) 

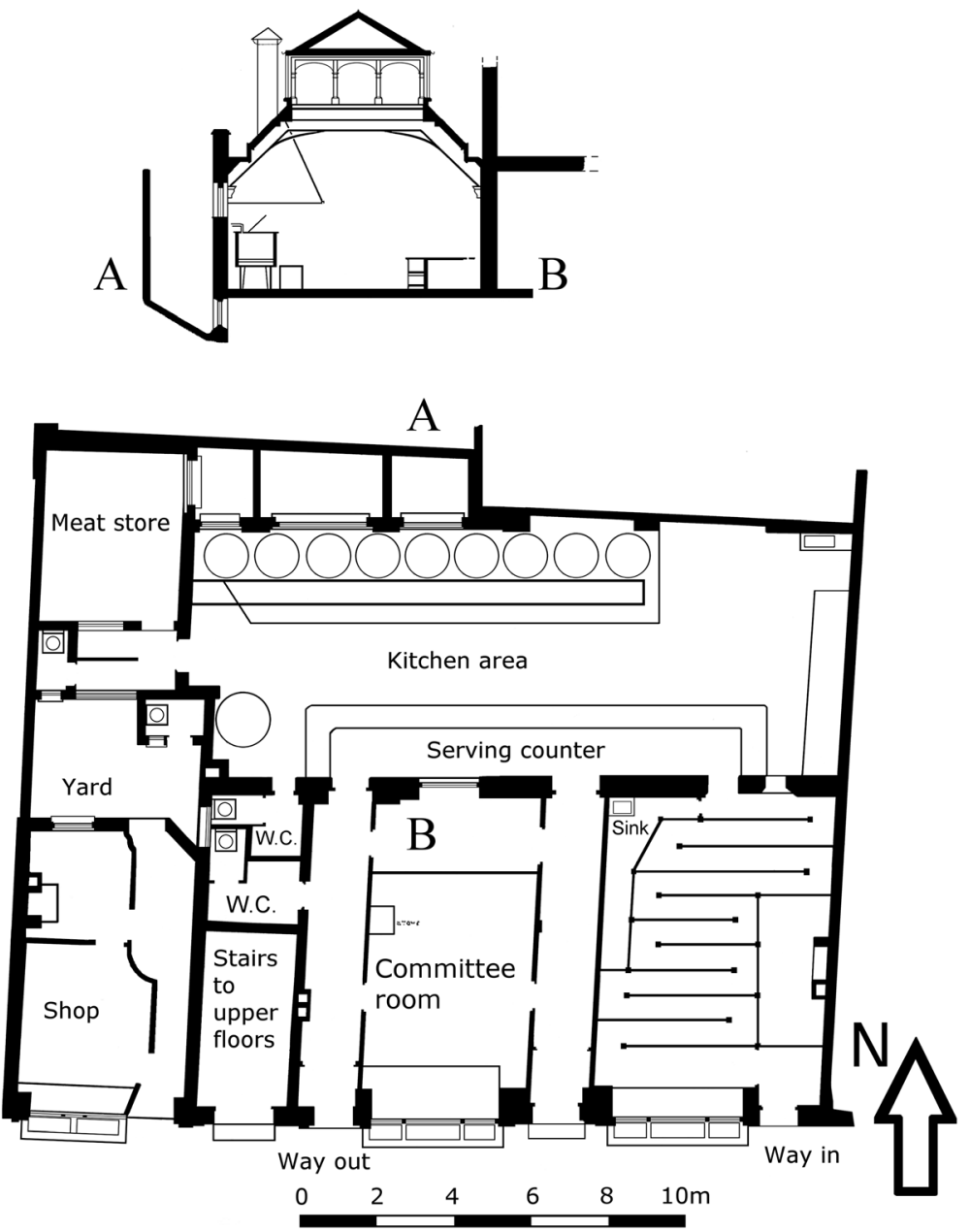

Fig. 11 Plan and section of the ground floor of the Soup Kitchen for the Jewish Poor, based on drawings published in the Builder (1903) (drawing: author)

female toilets and washing facilities. The process is shown in Fig. 12, taken from an unidentified, probably Jewish, journal from 1903. Figures 9 and 12 are somewhat idealistic. In reality, Butler Street would have been more crowded and the space in front of the counter was narrower; the illustrations may have tried to give the impression that there were not really many immigrants. However, Fig. 7 typifies the press portrayal of English soup kitchens (which is generally just as sympathetic to the poor) but portrays a grimmer reality inside the buildings.

The central door provided access to the committee room and the room in which applicants were interviewed, from which the kitchen could be supervised. The passageways, waiting areas, and kitchen had white-tiled walls to make cleaning easier. The upper floors, basement, and shop to the side had entirely separate entrances. The Builder (1903) stresses the economy with which the building was constructed. The whole building and land cost about $£ 10,000$, over ten times the cost of the Newcastle 


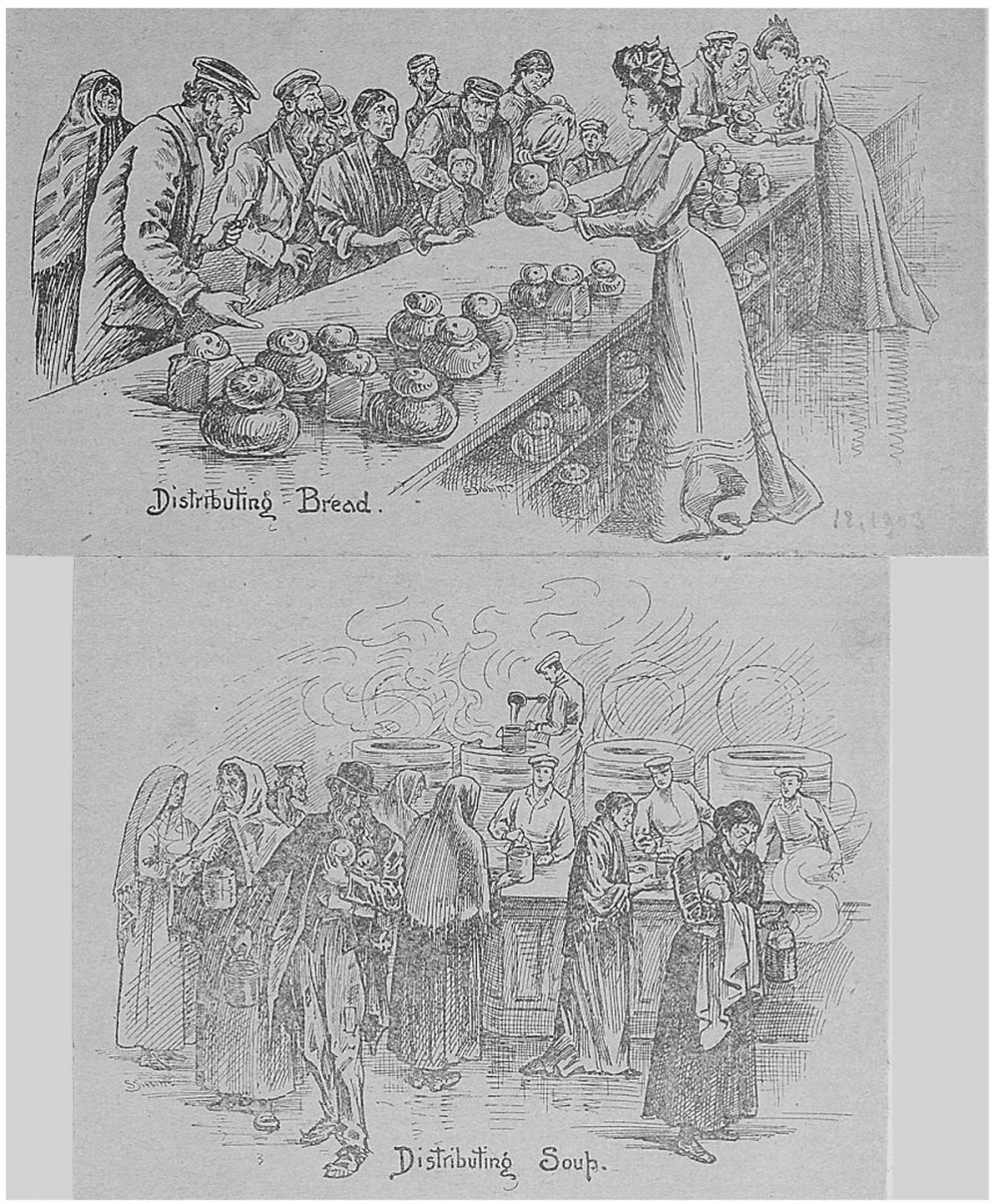

Fig. 12 Serving bread and soup at the Soup Kitchen for the Jewish Poor, Butler Street 1903 (courtesy of the Jewish Museum, London)

building. While Butler Street is about four times larger and the price included the land (earlier minutes estimated this at £3000) it seems to have been fitted out to a much higher standard than Newcastle.

\section{The Manchester Jewish Soup Kitchen}

\section{Documentary History}

The Jewish soup kitchen in Manchester had its first meeting in November 1895 (Manchester Jewish Soup Kitchen 1912). The committee was formed by local rabbis; the women present formed a sub-committee to organize fund-raising. By 1904, half of the main committee was made up of women. The kitchen opened three times a week from Chanukah (i.e., in early 1896) until Passover. The committee adopted the name 
"The Soup Kitchen for the Jewish Poor Manchester," after the London soup kitchen. In 1908 the name was changed to "The Manchester Jewish Soup Kitchen."

The soup kitchen opened at the back of a building on Lord Street in Cheetham Hill. These premises were enlarged in 1896, but proved unsatisfactory. The kitchen moved briefly to nearby Caernarvon Street in 1901 and then to 12 Park Place in 1902 while permanent premises were investigated. The committee located a site on the corner of Exchange Street (now Empire Street) and Southall Street, opposite the northeast corner of Strangeways Prison, on the western side of the Jewish community. Plans were drawn up by architect Thomas Bushell. Fundraising for the new building included a penny-brick fund by which less well-off donors could sponsor a brick for the cost of one penny.

Applicants for relief were considered the week before opening after handbills and posters in English and Yiddish had been distributed around the neighborhood. The investigating committee was made up of 12 men and 12 women, and was responsible for determining the genuineness of applicants, although casuals seem to have been regular recipients of relief. Dubious applications were passed to the Manchester Jewish Board of Guardians. Around 1000 applications for soup were made in 1904 . The kitchen also provided relief to "deserving" nonJewish applicants, by distributing tickets to both the local Christian ministers and the police. Michael Marks, the co-founder of department store Marks \& Spencer and an active committee member, made a substantial donation in 1905 for funding tickets specifically for non-Jewish applicants. The minute book records that soup kitchen openings were regularly attended by a police constable to ensure good order.

Each adult received a pint of beef soup and a one-pound loaf of bread free, with an additional loaf on Thursdays for the Sabbath; children received half the adult portion. The Thursday ration was increased in 1901, but the overall ration was reduced in 1904. Food boxes were distributed for Passover. The committee regularly requested samples of bread from the bakers, inspected the meat, and investigated when complaints were made about the food. Soup was distributed in numbered cans which were collected back at the end of each season and reallocated for the next. Kitchen hours were increased to four days a week and more soup cans had to be ordered in 1909 as demand increased; non-Jewish recipients had to bring their own containers. Casuals either ate in the kitchen using bowls provided or brought their own containers. In the 1930s, the soup was made with shin-beef, peas, barley, and beans (Manchester Jewish Soup Kitchen 1991).

The location for the Philanthropic Hall, as the purpose-built soup kitchen came to be known, was chosen as it seems to have been one of the few affordable vacant plots of land of the right size within the principal area of Jewish settlement. By 1906 the new building was complete; at the opening ceremony the Mayor of Manchester laid the foundation stone and the Mayor of Salford and others laid "memorial" stones. The first floor of the building was rented out to other Jewish community groups to generate income for the charity.

In 1942, the soup kitchen changed to a meals-on-wheels service for the elderly and moved to the suburbs (Manchester Jewish Soup Kitchen 1997). The building was converted into a factory and warehouse, and later housed a radio station and training school. 


\section{The Philanthropic Hall}

The building is two stories high and forms a wedge-shaped trapezium with sides measuring only $3.4 \mathrm{~m}$ (11 ft) on Empire Street to the north, $23 \mathrm{~m}(75 \mathrm{ft})$ along Southall Street to the west (the front façade), $14.5 \mathrm{~m}(48 \mathrm{ft})$ on the south overlooking a yard, and $20 \mathrm{~m}$ (66 ft) to the east where the wall is contiguous with the adjoining factory. Southall Street slopes downhill to the south, giving the southern end of the building a high ground floor ceiling level. The ground floor area of the building, where the kitchen was, is about $180 \mathrm{~m}^{2}\left(1940 \mathrm{ft}^{2}\right)$, much smaller than the premises at Butler Street, reflecting the smaller population served by the kitchen.

The north and west walls are built of red brick in a neo-classical style. The brick work is divided by horizontal string courses immediately below and above the windows on each floor and by vertical pilasters (Fig. 13). The door in the north wall, the principal door in the west wall and the gable over it, are ornamented with broken ogeeshaped pediments, each enclosing an obelisk. Over the principal door a terracotta panel reads "PHILANTHROPIC 56661906 HALL." The windows and doors have plain stone lintels. The roof is slate tiled. The south wall overlooking the factory yard is plain.

The doorway on Empire Street, on the north side, is to the upper floor only. On the west side there were originally two doors on either side of the main central door; these are now windows having been partly blocked up. The large doorway to the south of the central door was originally a window. The second ground-floor window from the south corner was originally a door which was probably the entrance to the store rooms and perhaps the first floor. These changes post-date the 1930s (a photograph from the 1930s shows a queue waiting for soup at the southernmost of the three contiguous doors). The outer two of the three doorways would have been the entrance and exit for the soup queue; the central door was probably the formal entrance to the committee room (reflecting the arrangement at the Butler Street building).

The exact layout of the interior of Philanthropic Hall has not been determined. Most original internal features on the ground floor have been removed. The few photographs held by the Manchester Jewish Museum and references in the minutes (Manchester

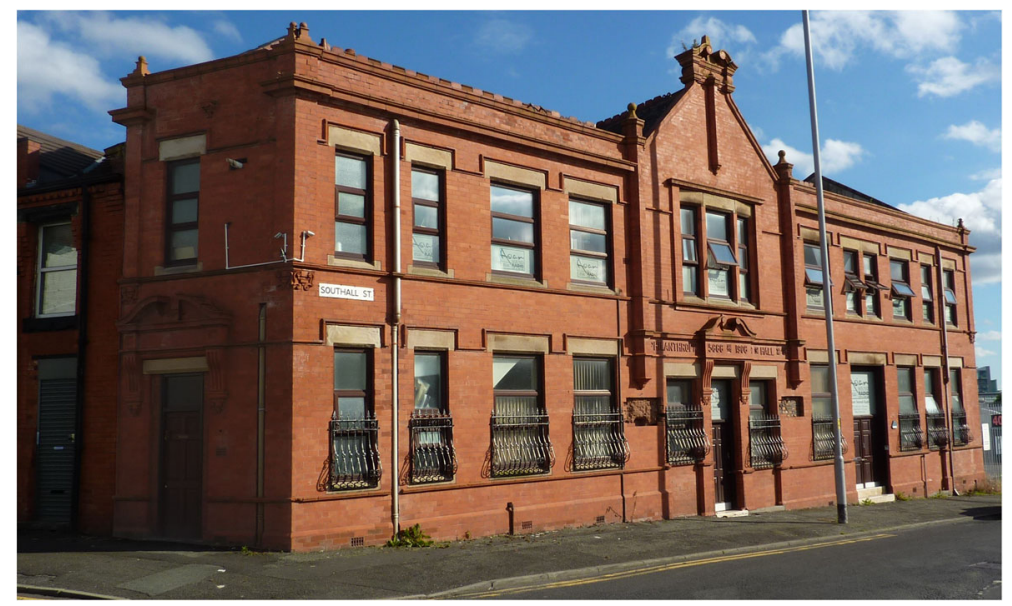

Fig. 13 The Philanthropic Hall, Manchester (photo: author) 
Jewish Soup Kitchen 1912, 1991) suggest that the layout was similar to the Butler Street building. Inside there was a waiting room with a maze, a serving area, a dining area with benches and tables, and a committee room (with fireplace), toilets (next to the kitchen), and the kitchen. Some of the interior walls were tiled, the floors were concrete and there were electric and gas lights. The serving area had three marble counters, partitions, and barriers. There was no shelter for the queue outside and the committee spent some time unsuccessfully trying to get one built on the adjoining land. Ventilating the steam from the kitchen presented problems: two of the windows were adapted to allow steam to escape and there was a ventilator in the roof. Chimneys at the north and south ends suggest the former locations of the boiler and fireplaces.

\section{Discussion}

The soup kitchens described above can be compared across a number of different dimensions to show how the poor would have experienced them and the charity being offered. In each case, the organizers of the charity thought hard about both the locations of their buildings and what the buildings looked like by investigating possible locations and engaging professionals to design the buildings using the latest technology. The picture is completed by policies expressed in the food being offered and the interaction between staff and clientele within the built environment.

At the outset, each of the soup kitchens used locations that were marginal, not in the sense that they were on the edges of urban areas but in the sense that they were located in less than desirable places, away from the commercial centers: in the case of the earliest incarnation of the London Jewish soup kitchen, a courtyard on the border between the City of London and the East End and in the case of the English Newcastle General Soup Kitchen, a disused poultry market which it shared with a military barracks for part of the Napoleonic Wars (Newcastle 1801). For the London Jewish soup kitchen the location was conveniently close to the synagogue and the core of the Jewish community. For the Newcastle General Soup Kitchen, the location may have been chosen simply because the premises were vacant and free, although there are examples of other soup kitchens located in barracks such as Plainpalais in Geneva (Fatio 1910) so fear of civil unrest may have been relevant to the decision. Reform by distant separation was not the intention of these buildings, unlike larger institutions such as prisons and asylums (Markus 1993) but nevertheless they were peripheral in terms of their visibility.

When the Newcastle General Soup Kitchen moved in the 1840s, it was to the basement of the new police station; again there may have been two reasons behind the choice, the fact that the premises were free and the possibility of importing discipline from the proximity of the police (although there is a later reference to disorderly queuing). The London Jewish soup kitchen moved between several locations in the mid-nineteenth century, but each time it was to a courtyard, sidestreet or alley location within the area of Jewish settlement. These locations would have been cheaper to rent, but would also have been inconspicuous and so less likely to arouse hostility from neighbors or shame on the part of the clientele while remaining readily accessible to the poor who lived in these neighborhoods. 
The locations chosen for Newcastle's General Soup Kitchen were not so convenient for the poor. The permanent General Soup Kitchen site was chosen in 1879 primarily because it was free and the kitchen did not have to move far. This new building was more prominent than earlier locations, but its design suggests that the committee was not entirely comfortable with its being on public display. The public face, the west façade, adopts the persona of the neighboring venerable seventeenth-century Hospital, built for "deserving freemen" of Newcastle rather than the starving urban proletariat. Its proportions are awkward because it has to blend in with the Hospital. The other parts of the building are completely plain in contrast to its contemporary neighbor, the gothic school (see Fig. 3). The General Soup Kitchen is apologetic; it pretends to be something other than what it is.

Until the early twentieth century, both Jewish soup kitchens chose had chosen discrete locations but opted for more prominent locations for their early twentieth century buildings, although not on major commercial thoroughfares. Each used a long street frontage to display its identity with ornate brickwork and well-designed proportions. The Jewish soup kitchens stand out from their neighbors; they are not ostentatious but they are designed to be noticed. The signage is in English, not Yiddish, perhaps with the intention of encouraging the new immigrants to assimilate but also communicating to the English and the Anglo-Jewish communities, providing reassurance to the English that the Jews were dealing with the immigration issue and expressing pride to the larger Jewish community. The buildings must have made a big impression on the poor, particularly new immigrants; here is a building representing security and permanence, and demonstrating that there was a larger prosperous AngloJewish community that they too could join.

All three surviving buildings were designed to produce and distribute substantial quantities of food in a short time by controlling the flow of ingredients, finished soup and people. They incorporated the latest technology and knowledge gleaned from the operation of other soup kitchens in their design. However the way in which the organization was carried out was markedly different between the English Newcastle General Soup Kitchen and the two Jewish soup kitchens. All three locations used mazes to control the flow of people through their buildings. However the mazes in Butler Street and Newcastle would have been very different to negotiate (we do not know for sure how the maze at the Manchester Jewish Soup Kitchen operated), and the poor would have approached and entered the buildings in very different ways.

The Newcastle General Soup Kitchen used the performance of feeding to dehumanise the poor. They were made to enter by a discrete side entrance through the narrowest door in the plainest building imaginable, hidden away up a courtyard away from the street. The interior was cold, damp, and dark, the maze was unwelcoming and claustrophobic, built for an inferior race of stunted humans. The food was distributed as if to farm animals, piped into a trough, no doubt under the scrutiny of the stern-faced men in stove-pipe hats who occupy most illustrations of English soup kitchens (e.g., Figure 7).

In contrast, poor Jews entered Butler Street and the Philanthropic Hall by a front entrance. The Butler Street maze is in the building's front room (in a house, this would be where guests would be received) and it was considerably more spacious, warm, light and humane. Uniformed staff or volunteer ladies served the poor across a counter, as valued customers (1930s photographs show similar arrangements in the Philanthropic 
Hall). The kitchens established personal contact between the poor and the middle class, in a process in which the middle class became temporarily the servants of the poor. The Jewish poor had to pay the price of deference and agreeing to be improved and become acculturated but the food was free. They (and the non-Jews whom these kitchens also fed) did not suffer the loss of dignity demanded in Newcastle.

The ingredients used for making soup were similar in English and Jewish soup kitchens, but the Jewish kitchens placed greater emphasis on food quality and most importantly they provided bread and Passover rations. The English General Soup Kitchen refused to provide bread or free food or to adapt their output on Fridays to Catholic requirements, and they provided nothing extra on religious holidays. The Jewish kitchens opened every winter without question. In contrast, the management General Soup Kitchen always delayed opening if it could.

There were also significant differences in philosophy between the Newcastle General Soup Kitchen and the Jewish Soup kitchens. The two Jewish charities were more independent of prevailing English expert views on charity and the poor (interestingly, Lady Rothschild's suggestion seems to adopt the English view) and of their respective Boards of Guardians. Manchester carried out its own investigations, as did London. London appears to have provided food liberally until 1874, and even after that very few applicants were rejected. The General Soup Kitchen delegated the investigation of applicants to subscribers and individuals such as church wardens and local overseers and, later on, the COS, adopting the prevailing authoritative view of the poor and charity. It used a single incident of "imposition" as a pretext for closing the charity for good, having refused to investigate; the Jewish kitchen in London investigated incidents of imposition and continued service. Finally, both Jewish communities developed longterm institutions and strategies for feeding and improving the poor. Their purpose-built buildings were designed to generate sufficient income from renting out surplus space to support the charity in the future. The General Soup Kitchen shoe-horned their premises onto a tiny plot of land because it was free but as a result the building could not generate additional income to sustain the charity when subscriptions fell.

\section{Charity as Reform, Archaeology as Reform}

The managers of the General Soup Kitchen adopted many of methods used by total institutions to shape and control the poor. Great efforts were made to separate the poor into deserving and undeserving and prevent indiscriminate charity by controlling the distribution of tickets. The process of receiving soup, once the poor had passed the test of whether they were deserving, was laborious and dehumanizing. The soup was dispensed efficiently but mechanically, and was withdrawn from all if the committee felt that there had been any imposition, perhaps as punishment. This practice complied with the prevailing Zeitgeist; the crusade against outdoor relief. The committee policies identified with those of the state welfare system that aimed to deter vagrancy and pauperism with the threat of the workhouse. It assumed the worst of the poor, that they were drinkers and lazy and would exploit the system if they could. The bare functionality of the building and its harshness are a clear indication of the type of charity on display. Charity does little more than keep the poor in their place. 
The Jewish community also used charity to impose self-discipline and cohesion (Lipman 1954). The Boards of Guardians tried to restrict immigration, to protect the middle class from a feared anti-Semitic backlash driven by fear of immigrants (Tanabaum 1997). However, by the late-nineteenth century, if not before, this rigor became rhetorical. The soup kitchens took the generous, humane approach evidenced by their policies and buildings, while paying lip service to English mainstream opinion in their fund-raising literature. They fed casuals (including non-Jews) and very few applicants seem to have been rejected.

Although Anglo-Jewish charitable mores were influenced from time to time by prevailing English cultural values, their core beliefs were retained. Traditional Jewish charity investigated the poor categorizing them as undeserving - schnorrers or scroungers, who were excluded from support - or deserving. It often privileged family and local poor over foreigners, but charity to all needy, foreign and non-Jewish, was still a religious obligation. The poor were to be fed before any investigation, whereas clothing was only provided after investigation (Cohen 2009). The control exercised by Jewish charities focused on promoting education and healthcare, and on improving employment prospects by apprenticeships and loans for equipment or stock; the goal was to raise the poor out of poverty, not simply to alleviate poverty's worst effects (Liedtke 1998; Lipman 1959). Jewish charities believed that most immigrants were suffering from "transient poverty" and that if given enough help they would change. In the long run, the process was effective: circa 1856, nearly $20 \%$ of the Jewish population in London was receiving assistance from the soup kitchen; by 1900 the figure was about $6 \%$, despite the continuing increase in immigration. (Some of the improvement was no doubt due to a national improvement in employment conditions.)

At the opening of the Butler Street building, Herman Landau, a Polish Jew who had come to England poor and become a wealthy banker (Endelman 2002), avowed that, even if political economy forbade soup kitchens which could be accused of "being more merciful than wise," mercy would prevail. The buildings with their humane atmosphere made the process of improvement more benign and effective. Control based on kindness may have proved more effective than dominance and coercion.

Simply by reading the reports and minute books of the charities concerned, one might not perceive the great differences between the two very different types of charity on offer. By looking at the physical aspects, the buildings and spaces and how they were used we can understand the lived experience of the poor the impact on charity on them and how they respond. What is clear is that palliative and piecemeal approaches to welfare or charity are likely to be ineffective (if the goal is to prevent poverty rather than temporarily alleviate distress) and even counterproductive, particularly if the approach is coercive rather than encouraging. While these lessons have been learned by some, the ongoing debate and reform programs suggest that not all have learned.

Acknowledgments I am grateful for the assistance of Aubrey Newman of Leicester University, the National Trust (England and Wales), and in particular Gerard New, Lynn Redhead and Joanne Linton, Shurjat Ali of Asian Sound Radio, Manchester, Sharman Kadish of Jewish Heritage UK, the London Metropolitan Archive, Manchester Libraries, Information and Archives, the Tyne \& Wear Archives, Alexandra Grime of the Manchester Jewish Museum, and Elizabeth Selby of the Jewish Museum, London. This study forms part of a larger research project funded by a grant from the Arts and Humanities Research Council under the 
Midlands3Cities Doctoral Training Partnership. Thank you also to the reviewers of the paper whose comments have been helpful and to Megan Springate and Kim Christensen for the hard work in putting together the original conference session and this volume.

Open Access This article is distributed under the terms of the Creative Commons Attribution 4.0 International License (http://creativecommons.org/licenses/by/4.0/), which permits unrestricted use, distribution, and reproduction in any medium, provided you give appropriate credit to the original author(s) and the source, provide a link to the Creative Commons license, and indicate if changes were made.

\section{References}

Andrew, D. (1989). Philanthropy and Police: London Charity in the Eighteenth Century, Princeton University Press, Princeton.

Architectural Association. (1891). The Architectural Association Sketchbook: New Series Volume 11, Architectural Association, London.

Baglee, C. (1971). The Holy Jesus Hospital: A Short History, Frank Graham, Newcastle.

Baugher, S. (2001). Visible charity: the archaeology, material culture, and landscape design of New York City's municipal almshouse complex, 1736-1797. International Journal of Historical Archaeology 5: 175-202.

Brodie, A., Croom, J., and Davies, J. (2002). English Prisons: An Architectural History, English Heritage, Swindon.

Builder. (1903). Soup kitchen for the Jewish poor. The Builder, 24 January, p. 91.

Casella, E. (2001). To watch or restrain: female convict prisons in nineteenth-century Tasmania. International Journal of Historical Archaeology 5: 45-72.

Casella, E. (2007). The Archaeology of Institutional Confinement, University Press of Florida, Gainesville.

Checkland, O. (1980). Philanthropy in Victorian Scotland: Social Welfare and the Voluntary Principle, John Donald, Edinburgh.

Cohen, A. (1943). An Anglo-Jewish Scrapbook 1600-1840: A Jew Through English Eyes, Callingold, London.

Cohen, M. R. (2009). Poverty and Charity in the Jewish Community of Medieval Egypt, Princeton University Press, Princeton.

Colquhoun, P. (1799). Suggestions Offered to the Consideration of the Public, and in Particular to the More Opulent Classes of the Community, for the Purpose of Reducing the Consumption of Bread Corn: And Relieving at the Same Time the Labouring People. By the Substitution of Other Cheap, Wholesome, and Nourishing Food; and Especially by Means of Soup Establishments, \&c. Colquhoun, London

Cordeiro, R. (2012). Filantropia: As Cozinhas Económicas de Lisboa (1893-1911). Master's thesis, Instituto Universitário de Lisboa. https://repositorio.iscte.pt/handle/10071/5510 accessed December 12, 2013.

De Cunzo, L. A. (1995). Reform, respite, ritual: an archaeology of institutions: the Magdalen Society of Philadelphia, 1800-1860. Historical Archaeology 29(3): 1-168.

Digby, A. (1989). British Welfare Policy: Workhouse to Workfare, Faber and Faber, London.

Endelman, T. M. (2002). The Jews of Britain, 1656 to 2000, University of California Press, Berkeley.

Family Welfare Association (1887). Charity and Food: Report of the Special Committee upon Soup Kitchens, Children's Breakfasts and Dinners, and Cheap Food Supply, Spotiswode, London.

Fatio, G. (1910). Coup d'oeil historique sur les oevres philanthropiques genevoises. Bureau Centre de Bienfaisance 44me Rapport Annuel, Bureau Centre de Bienfaisance, Geneva, pp. 55-86.

Foucault, M. (1979). Discipline and Punish: The Birth of the Prison, Sheridan, A. (trans.), Vintage, New York.

Fraser, L. (1996). "Four percent Philanthropy": social architecture for East London Jewry, 1850-1914. In Kadish, S. (ed.), Building Jerusalem: Jewish Architecture in Great Britain, Vallentine Mitchell, London, pp. 167-192.

Fraser, D. (2009). The Evolution of the British Welfare State: A History of Social Policy Since the Industrial Revolution, Palgrave Macmillan, Basingstoke.

General Report. (1800). General Report of the Committee of Subscribers, to a Fund for the Relief of the Industrious Poor Resident in the Cities of London and Westminster, the Borough of Southwark, and the Several Out-Parishes of the Metropolis, J. Richardson, London.

General Soup Kitchen. (1867). General Soup Kitchen Accounts, 17 January 1820 to 2 March 1867: CHX3/2/ 1, Tyne \& Wear Archives, Newcastle-upon-Tyne. 
General Soup Kitchen. (1870). General Soup Kitchen Management Committee Minutes 10 February 1862 to 31 January 1870: CHX3/1/1, Tyne \& Wear Archives, Newcastle-upon-Tyne.

General Soup Kitchen. (1879). General Soup Kitchen Management Committee Minutes 7 February 1870 to 5 May 1879: CHX3/1/2, Tyne \& Wear Archives, Newcastle-upon-Tyne.

General Soup Kitchen. (1900). General Soup Kitchen Management Committee Minutes 25 August 1879 to 10 December 1900: CHX3/1/3, Tyne \& Wear Archives, Newcastle-upon-Tyne.

Goffman, E. (1961). Asylums: Essays on the Social Situation of Mental Patients and Other Inmates, Anchor, New York.

Huey, P. (2001). The almshouse in Dutch and English colonial North America and its precedent in the old world: historical and archaeological evidence. International Journal of Historical Archaeology 5: 123-154.

Humphreys, R. (1995). Sin, Organized Charity, and the Poor Law in Victorian England, St. Martin's Press, London.

Hurren, E. T. (2007). Protesting about Pauperism: Poverty, Politics and Poor Relief in Late-Victorian England, 1870-1900, Boydell and Brewer, Woodbridge.

Hyamson, A. (1908). A History of the Jews in England, Chatto and Windus, London.

Illustrated London News. (1862). The distribution of soup: the Society of Friends' soup-kitchen, ball street, lower Moseley street, Manchester. Illustrated London News 41(1175): 558, 561.

Illustrated London News. (1879). The Jews' soup kitchen, Spitalfields. Illustrated London News 75(2117): $589,591$.

Jewish Care. (2015). Jewish care - our history. <https://www.jewishcare.org/about-us>, accessed 24 May 2015.

Jewish Year Book. (1907). The Jewish Yearbook: An Annual Record of Matters Jewish, 5667, Greenberg, London.

Johnson, M. (2010). English Houses 1300-1800: Vernacular Architecture, Social Life, Pearson, Harlow.

Liedtke, R. (1998). Jewish Welfare in Hamburg and Manchester c. 1850-1914. Oxford University Press, Oxford.

Lipman, V. D. (1954). Social History of the Jews in England, 1850-1950, Watts, London.

Lipman, V. D. (1959). A Century of Social Service, 1859-1959: The Jewish Board of Guardians, Routledge and Kegan Paul, London.

Lipman, V. D. (1981). Jewish settlement in the east end 1840-1940. In Newman, A. (ed.), The Jewish East End, Jewish Historical Society of England, London, pp. 17-40.

Lipman, V. D. (1990). A History of the Jews in Britain since 1858, Leicester University Press, Leicester.

Lipman, V. D. (1994). Social History of the Jews in England, 1850-1950, 2nd ed., Watts, London.

MacKenzie, E. (1827). A Descriptive and Historical Account of the Town and County of Newcastle-uponTyne, MacKenzie and Dent, Newcastle-upon-Tyne.

Magnus, L. (1909). The Jewish Board of Guardians 1859-1909, Jewish Board of Guardians, London.

Maimonides. (1979). The Code of Maimonides, Book Seven: The Book of Agriculture, Klein, I. (trans.) Yale University Press, New Haven, CT.

Manchester Jewish Soup Kitchen. (1912). Minute Book 1895-1912: GB127.M151. Manchester Libraries, Information and Archives, Manchester.

Manchester Jewish Soup Kitchen. (1991). Minute Book 1932-1991: GB127.M151. Manchester Libraries, Information and Archives, Manchester.

Manchester Jewish Soup Kitchen. (1997). Manchester Jewish Soup Kitchen Centenary Year Brochure, 18971997: GB127.M1514/4/1. Manchester Libraries, Information and Archives, Manchester.

Marks, K. (2014). The Archaeology of Anglo-Jewry in England and Wales 1656 - c. 1880. Archaeopress, Oxford.

Markus, T. (1993). Buildings and Power: Freedom and Control in the Origin of Modern Building Types, Routledge, London.

May, T. (2005). The Victorian Workhouse, Shire, Oxford.

McQueen, P. (1995). Order, Industry, Virtue: Count Rumford and Eighteenth Century Poor Relief. Master's thesis, Simon Fraser University, Canada. <http://www.collectionscanada.gc.ca/obj/s4/f2/dsk1/tape9 /PQDD_0023/MQ51416.pdf>, accessed April 29, 2014.

Monthly Magazine. (1800). Provincial Occurrences, Monthly Magazine 8: 917.

Newcastle. (1801). An Impartial History of the Town and County of Newcastle upon Tyne, and Its Vicinity. John Baillie, Newcastle-upon-Tyne.

Newcastle Corporation. (1855). Newcastle City Council General Committees Minutes 24 January 1839 to 1 May 1855: MD.NC/94/1. Tyne \& Wear Archives, Newcastle-upon-Tyne. 
Newcastle Corporation. (1879). Manors General Soup Kitchen Plans Submitted for Council Approval 6 November 1879: T186/8889, Tyne \& Wear Archives, Newcastle-upon-Tyne.

Owen, D. (1965). English Philanthropy, 1660-1960, Oxford University Press, London.

Parson, W., and White, W. (1827). History, Directory, and Gazetteer, of the Counties of Durham and Northumberland, and the Towns and Counties of Newcastle-upon-Tyne and Berwick-upon-Tweed, William White, Newcastle.

Piddock, S. (2007). A Space of Their Own: The Archaeology of Nineteenth-Century Lunatic Asylums in Britain, South Australia, and Tasmania, Springer, New York.

Prochaska, F. (1990). Philanthropy. In Thompson, F. (ed.), The Cambridge Social History of Britain, 17501950, Vol. 3, Cambridge University Press, Cambridge, pp. 357-394.

Redlich, F. (1971). Science and charity: count Rumford and his followers. International Review of Social History 16: 184-216.

Roberts, M. (2004). The Making of English Morals: Voluntary Association and Welfare Reform in England 1787-1886, Cambridge University Press, Cambridge.

Rozin, M. (1999). The Rich and the Poor: Jewish Philanthropy and Social Control in Nineteenth-Century London, Sussex Academic Press, Brighton.

Russell, C., and Lewis, H. S. (1900). The Jew in London, T. Fisher Unwin, London.

Sherman, S. (2001). Imagining Poverty: Quantification and the Decline of Paternalism, Ohio State University Press, Columbus.

Soup Kitchen for the Jewish Poor. (1889a). General Committee, Minutes, Annual Accounts, 1872-1889: ACC/ 2942/002, Metropolitan Archives, London.

Soup Kitchen for the Jewish Poor. (1889b). General Committee, Minutes, Annual General Meeting, 18901907: ACC/2942/003, Metropolitan Archives, London.

Soup Kitchen for the Jewish Poor. (1889c). Building Committee: With Related Correspondence, 1900-1903: ACC/2942/007, Metropolitan Archives, London.

Spencer-Wood, S. (2001). Introduction and historical context to the archaeology of seventeenth- and eighteenth-century almshouses. International Journal of Historical Archaeology 5: 115-122.

Stedman Jones, G. (2013). Outcast London: A Study in the Relationship Between Classes in Victorian Society, Verso, London.

Stein, S. (1959). Some Ashkenazi charities in London at the end of the eighteenth and the beginning of the nineteenth centuries. Transactions (the Jewish Historical Society of England) 20: 63-81.

Sykes, J. (1833). Local Records: Or, Historical Register of Remarkable Events, Which Have Occurred in Northumberland and Durham, Newcastle-upon-Tyne, and Berwick-upon-Tweed from the Earliest Period of Authentic Record to the Present Time, Sykes, Newcastle-upon-Tyne.

Tanabaum, S. L. (1997). Philanthropy and identity: gender and ethnicity in London. Journal of Social History 30: $937-961$.

Vaughan, L. (2002). The unplanned ghetto: immigrant work patterns in $19^{\text {th }}$ century Manchester. Paper given at the $10^{\text {th }}$ Conference of the International Planning History Society, University of Westminster, London.

Williams, W. (1976). The Making of Manchester Jewry, 1740-1875, Manchester University Press, Manchester.

Wolf, L. (1934). Early Ashkenazi charities in London. In Roth, C. (ed.), Essays in Jewish history, Jewish Historical Society, London, pp. 185-201. 